Revista Española de Derecho Internacional Sección JURISPRUDENCIA DIPr Vol. 67/2, julio-diciembre 2015, Madrid, pp. 183-238 http://dx.doi.org/10.17103/redi.67.2.2015.3b (c) 2015 Asociación de Profesores de Derecho Internacional y Relaciones Internacionales ISSN: 0034-9380; E-ISSN: 2387-1253

\title{
B) JURISPRUDENCIA ESPAÑOLA Y COMUNITARIA DE DERECHO INTERNACIONAL PRIVADO *
}

\author{
Selección y coordinación a cargo de \\ Santiago Álvarez GoNZÁlez \\ Catedrático de Derecho internacional privado \\ Universidad de Santiago de Compostela
}

SUMARIO: 1. TRIBUNAL DE JUSTICIA: ESPACIO DE LIBERTAD, SEGURIDAD Y JUSTICIA.-1.1. Ámbito de aplicación del Reglamento 44/2001.-1.2. Competencia judicial internacional en materia civil y mercantil.-1.3. Competencia judicial internacional en materia de responsabilidad parental.-1.4. Reglamento 1346/2000.-1.5. Proceso monitorio europeo.-2. PRÁCTICA ESPAÑOLA: DERECHO JUDICIAL INTERNACIONAL.-2.1. Aplicación judicial del Derecho extranjero.-3. PRÁCTICA ESPAÑOLA: DERECHO CIVIL INTERNACIONAL.-3.1. Filiación: gestación por sustitución.-3.2. Procesos matrimoniales.-3.3. Ley aplicable a los efectos del matrimonio.-3.4. Responsabilidad del fabricante por los productos defectuosos.-3.5. Sucesiones internacionales.

\section{TRIBUNAL DE JUSTICIA: ESPACIO DE LIBERTAD, SEGURIDAD Y JUSTICIA}

\section{1. Ámbito de aplicación del Reglamento 44/2001}

2015-20-Pr

REGLAMENTO BRUSELAS I._Ámbito de aplicación del Reglamento 44/2001.Arbitraje.-Reconocimiento y ejecución de laudos arbitrales dictados en el extranjero.

* Esta crónica es continuación de la publicada en REDI, 2015-1. La selección se ha efectuado sobre resoluciones dictadas durante los años 2014 y 2015. Colaboran en la presente crónica, Santiago 
Preceptos aplicados: arts. 1 y 71 del Reglamento 44/2001.

\section{Sentencia del Tribunal de Justicia (Gran Sala) de 13 de mayo de 2015, asunto C-536/13, "Gazprom» OAO y Lietuvos Respublika. Ponente: M. Safjan.}

\section{F.: curia.europa.eu.}

36. A este respecto debe recordarse primeramente que, tal y como se ha indicado en el apartado 28 de la presente sentencia, el arbitraje no está incluido en el ámbito de aplicación del Reglamento n. ${ }^{\circ} 44 / 2001$, ya que éste sólo rige los conflictos de competencias entre los órganos jurisdiccionales de los Estados miembros. Como los tribunales arbitrales no son órganos jurisdiccionales estatales, en el caso de autos no existe tal conflicto, en el sentido de dicho Reglamento.

37. Seguidamente, en cuanto atañe al principio de confianza recíproca, que los Estados miembros otorgan a sus respectivos sistemas jurídicos e instituciones judiciales y que se plasma en la armonización de las normas de competencia de los órganos jurisdiccionales sobre la base del sistema establecido por el Reglamento n. ${ }^{\circ} 44 / 2001$, debe senalarse que, en las circunstancias del asunto principal, dado que la orden conminatoria ha sido dictada por un tribunal arbitral, no nos encontramos ante una vulneración del citado principio por la injerencia de un órgano jurisdiccional de un Estado miembro en las competencias de un órgano jurisdiccional de otro Estado miembro [...].

43. Dado que el convenio de Nueva York regula una materia excluida del ámbito de aplicación del Reglamento $n{ }^{\circ}$ 44/2001, no se trata de una "materia particular» en el sentido del artículo 71, apartado 1, de dicho Reglamento. En efecto, el citado artículo 71 sólo regula las relaciones entre el Reglamento $n .^{\circ} 44 / 2001$ y los convenios relativos a materias particulares incluidas en el ámbito de aplicación de dicho Reglamento [...].

Nota. 1. El caso que nos ocupa es sencillo de presentar: en Estocolmo se dicta un laudo arbitral en el que se conmina al ministerio de energía de Lituania a retirar o reducir determinadas pretensiones que dicho ministerio había planteado ante los tribunales lituanos. Estos últimos han de enfrentarse a la determinación de la eficacia de dicho laudo en Lituania, tanto por vía directa — se solicitó por parte de la sociedad Gazprom, demandante en el proceso arbitral, el reconocimiento del laudo arbitral en Lituania-como indirecta; en tanto en cuanto la orden conminatoria podía afectar a procedimientos judiciales ya abiertos en Lituania.

En este contexto el Tribunal Supremo de Lituania dirige tres cuestiones prejudiciales al Tribunal de Luxemburgo que, tal como resume éste, plantean en esencia si el Reglamento Bruselas I «se opone a que un órgano jurisdiccional de un Estado miembro reconozca y ejecute, o a que se niegue a reconocer y ejecutar, un laudo arbitral que prohíbe a una parte formular determinadas pretensiones ante un órgano jurisdiccional de ese Estado miembro» (núm. 27 de la sentencia).

2. La respuesta a esta pregunta podría ser breve, clara y concisa. El Tribunal de Justicia podría simplemente contestar que dado que el arbitraje es una materia ex-

\footnotetext{
Álvarez González, Rafael Arenas García, Carmen Azcárraga Monzonís, Alegría Borrás, Laura Carballo Piñeiro, Ángel Espiniella Menéndez, Joaquim J. Forner i Delaygua, Mónica Herranz Ballesteros, Pilar Jiménez Blanco, Nerea Magallón Elósegui, Javier Maseda Rodríguez, Pedro A. De Miguel Asensio, Paula Paradela Areán, Alexia Pato y Marta Requejo Isidro, de las Universidades de Barcelona, Autónoma de Barcelona, Autónoma de Madrid, Complutense de Madrid, Deusto, Oviedo, Santiago de Compostela, y UNED, y del Max Planck Institute Luxemburg for International, European and Regulatory Procedural Law.
} 
cluida del ámbito de aplicación del Reglamento 44/2001 [art. 1.2.d) del Reglamento] y el supuesto se refiere al reconocimiento de un laudo arbitral, no existe nada en el Reglamento que impida que u obligue a que los órganos jurisdiccionales de los Estados miembros reconozcan dicho laudo. La eficacia en los Estados miembros de los laudos arbitrales dictados en otros Estados miembros está excluida del ámbito de aplicación del Reglamento 44/2001. Éste en nada afecta al régimen del reconocimiento o ejecución de los laudos arbitrales. En realidad, ésta sería una consecuencia clara y poco dudosa de la exclusión del arbitraje del ámbito de aplicación del Reglamento.

Pero, tal como se indica en las Conclusiones presentadas por el Abogado General, Sr. Melchior Wathelet «si ello fuera tan sencillo, el Tribunal de Justicia no habría declarado incompatible con el Reglamento Bruselas I la "anti-suit injunction" que fue objeto de su Sentencia Allianz y Generali Assicurazioni Generali» (núm. 87 de las Conclusiones).

Efectivamente, tras la Sentencia Allianz de 10 de febrero de 2009 (impropiamente conocida como West Tankers, véase PFEIFFER, Th., "Pfeiffer on West Tankers», Conflict of Laws, 12 de febrero de 2009, http://conflictoflaws.net/2009/pfeiffer-on-west-tankers/) no resulta ya posible mantener que el hecho de que un determinado procedimiento esté excluido del ámbito de aplicación del Reglamento implica que el Reglamento no podrá aplicarse en relación con ese procedimiento; es por ello que en este caso el razonamiento del Tribunal ha de ir un poco más allá de la constatación de que estamos ante el reconocimiento de un laudo arbitral, y detallar en qué forma la doctrina sentada en la Sentencia Allianz afecta al caso Gazprom. Recordemos que en aquella mantuvo que no era compatible con el Reglamento 44/2001 una decisión de un tribunal británico en la que se ordenaba a una sociedad que no continuara con un procedimiento iniciado en Italia, procedimiento que sí entraba en el ámbito de aplicación del Reglamento.

En el caso Gazprom también nos encontramos con que se trata de determinar de qué forma incide el Reglamento Bruselas I en un procedimiento excluido del ámbito de aplicación del Reglamento, pero que afecta a otro que sí se encuentra regido por éste. Dada la doctrina sentada en Allianz es razonable, por tanto, la cuestión prejudicial que nos ocupa.

El Tribunal de Luxemburgo mantiene en Gazprom que el Reglamento en nada afecta al reconocimiento del laudo arbitral dictado en Estocolmo. La justificación de la diferencia de resultado entre Allianz y Gazprom está en que en la primera decisión la orden conminatoria había sido adoptada por un órgano jurisdiccional, mientras que en la segunda nos encontramos ante un laudo arbitral. Esta diferencia es esencial ya que, según el Tribunal de Justicia, el Reglamento solamente se ocupa de los conflictos de competencia entre órganos jurisdiccionales. Las relaciones entre los tribunales arbitrales y los órganos jurisdiccionales de ninguna forma están afectadas por el Reglamento, por lo que no cabe que éste incida en modo alguno en el reconocimiento en Lituania del laudo arbitral dictado en Estocolmo (núms. 35 y 36 de la sentencia). Además, en el caso Gazprom la orden conminatoria no podría implicar que se acabara imponiendo una sanción a aquel contra la que se dirige en caso de incumplimiento, a diferencia de lo que sucedía en el caso Allianz, lo que de acuerdo con el Tribunal de Justicia también es una diferencia relevante (núm. 40 de la sentencia).

Si dejamos aparte este último argumento del Tribunal, resulta que la diferencia entre Allianz y Gazprom que justifica llegar a soluciones divergentes en uno y otro caso, está en que en la primera estaba en juego la confianza recíproca entre órganos 
jurisdiccionales de distintos países y, en cambio, en el caso Gazprom dicha confianza no está afectada por tratarse de un conflicto entre un órgano jurisdiccional y un tribunal arbitral (núm. 37 de la sentencia).

3. De acuerdo con lo que hemos visto, un caso que hace diez años, probablemente, no hubiera justificado el planteamiento de una cuestión prejudicial por ser clara la interpretación del Derecho europeo relevante para la materia, ha permitido aclarar la jurisprudencia sentada en el caso Allianz, reduciéndola a los casos en los que sean órganos jurisdiccionales los que limiten la capacidad de conocimiento de otro órgano jurisdiccional ubicado en un Estado miembro. Se ratifica así que los procedimientos que se desarrollan ante tribunales arbitrales están excluidos del ámbito de aplicación del Reglamento 44/2001. Esta exclusión implica que, en contra de lo que había planteado el órgano jurisdiccional remitente (véanse núms. 70 y ss. de las Conclusiones), el Convenio de Nueva York de 1958 no puede ser considerado como un convenio en materia particular de los previstos en el art. 71 del Reglamento, sino que se trata de un instrumento que regula materias excluidas del ámbito de aplicación del Reglamento (véase núm. 43 de la sentencia). Ciertamente, la cuestión no es menor, pues pese a que tanto considerarlo un convenio en materia particular como excluir el arbitraje del ámbito de aplicación del Reglamento conducirían a resultados muy parecidos, la primera solución no impediría que en aquellas cuestiones que no estuvieran reguladas por el convenio en materia particular se aplicase el Reglamento. Esta posibilidad, como hemos visto, queda excluida.

Nos encontramos, por tanto, ante una decisión en que por primera vez en varias en vez de producirse una extensión del ámbito de aplicación del Reglamento en relación con el arbitraje, concluye con el reconocimiento de los límites del Reglamento en materia arbitral. No se retrocede respecto a Allianz pero tampoco se avanza. Deberemos esperar a nuevas resoluciones para ver cómo evoluciona el «frente» entre el Reglamento Bruselas I y el arbitraje y, en concreto, será interesante ver si la interpretación que el Tribunal hace en este punto del Reglamento Bruselas I bis y Bruselas I son coincidentes. Sin poder entrar aquí en ello no puede dejar de señalarse que en las Conclusiones del Abogado General se mantiene que el Reglamento Bruselas I bis no hubiera permitido al Tribunal de Luxemburgo llegar a la solución que mantuvo en la Sentencia Allianz en aplicación del Reglamento 44/2001. Esta parte de las Conclusiones del Abogado General no presentan interés directo para el caso objeto de las cuestiones prejudiciales que nos ocupan, ya que en ellas se solicitaba interpretar este Reglamento 44/2001 y no el Reglamento 1215/2012; pero lo llamativo del planteamiento merece que se haga mención al mismo (véanse núms. 127 y ss. de las Conclusiones). Quizás pudiera objetarse al razonamiento que no tiene en cuenta la diferencia que existe entre la determinación de la competencia para conocer sobre la cuestión principal planteada y sobre los incidentes que se originan en el mismo procedimiento; pero ahora dejaremos esto aquí porque no se trata más que de una advertencia de cara al futuro sin transcendencia directa para la Sentencia que comentamos.

4. En definitiva, sin Allianz Gazprom no hubiera tenido sentido. El que la primera haya hecho posible que se haya tenido que plantear una cuestión prejudicial para determinar si, pese a la dicción del art. 1.2 del Reglamento 44/2001, entra o no en su ámbito de aplicación el reconocimiento en un Estado miembro de un laudo arbitral dictado en otro Estado miembro, podría ser un indicio de que algún problema hay con las relaciones entre el Reglamento 44/2001 y el arbitraje, con el Tribunal de Luxemburgo o con ambos. En cualquier caso, el perjudicado parece ser la seguridad 
jurídica, que se resiente cuando algo tan nítido como debería ser el tema objeto de la cuestión prejudicial planteada, precisa ser aclarado.

\author{
Rafael Arenas García \\ Universidad Autónoma de Barcelona \\ http://dx.doi.org/10.17103/redi.67.2.2015.3b.01
}

\title{
1.2. Competencia judicial internacional en materia civil y mercantil
}

2015-21-Pr

COMPETENCIA JUDICIAL INTERNACIONAL.-Derechos de autor-Competencias especiales en materia delictual o cuasidelictual.-Determinación del lugar del hecho dañoso.-Fotografías difundidas a través de internet.

Preceptos aplicados: art. 5.3 del Reglamento 44/2001.

Sentencia del Tribunal de Justicia (Sala 4. ${ }^{\text {a }}$ ), de 22 de enero de 2015, asunto C-441/13, Pez, Hejduk vs. EnergieAgentur. Ponente: M. Safjan.

\section{F.: curia.europa.eu.}

El art. 5, punto 3, del Reglamento (CE) n. ${ }^{\circ} 44 / 2001$ del Consejo, de 22 de diciembre de 2000, relativo a la competencia judicial, el reconocimiento y la ejecución de resoluciones judiciales en materia civil y mercantil, debe interpretarse en el sentido de que, en caso de una supuesta vulneración de los derechos de autor y de los derechos afines a los derechos de autor garantizados por el Estado miembro del órgano jurisdiccional ante el que se haya ejercitado la acción, dicho órgano jurisdiccional será competente, en virtud del lugar de materialización del daño, para conocer de una acción de responsabilidad por la vulneración de esos derechos cometida al ponerse en línea fotografías protegidas en un sitio de Internet accesible desde su circunscripción territorial. Dicho órgano jurisdiccional sólo será competente para conocer del daño causado en el territorio del Estado miembro al que pertenece.

Nota. 1. Nos hallamos ante una Sentencia del Tribunal de Justicia que versa sobre la violación de los derechos de autor, o afines a derechos de autor, en Internet, cometida al publicar unas fotografías en una página web que opera bajo el dominio de primer nivel de un Estado miembro (Alemania), diferente de aquél en que el titular del derecho tiene su domicilio (Austria) y donde ha sido interpuesta la demanda. Se trata de una fotógrafa profesional de arquitectura, la Sra. Hejduk, autora de obras fotográficas que representan los trabajos del Sr. Reinberg. El Sr. Reinberg utilizó las fotografías de sus obras - con el consentimiento de la autora- en un coloquio organizado por la demandada Energie Agentur, quien a su vez las colgó en una página web alemana sin su autorización.

2. En este asunto la pregunta de la cuestión prejudicial gira en torno a los criterios atributivos de la competencia judicial del art. 5.3 del Reglamento 44/2001 (RBI, hoy art. 7.3 del Reglamento Bruselas I bis) en el caso de una vulneración de un derecho patrimonial de autor cometido a través de Internet, en el que no es fácil localizar territorialmente la materialización del daño. Con anterioridad, el TJUE ha tenido ocasión de tratar temas similares a través de las Sentencias Pinckney (REDI, 2014-4Pr, con nota de Maseda Rodríguez, J., pp. 251-254), y la Sentencia eDate Advertising (REDI, 2012-7-Pr, con nota de LEIN, E., pp. 193-198). Sin embargo el supuesto en esta 
ocasión presenta ciertas particularidades que llevan a las partes a centrar el debate en la posibilidad de proyectar la doctrina de una u otra resolución a este supuesto concreto.

3. Empecemos desde el principio. La expresión «lugar donde se hubiere producido o pudiera producirse el hecho dañoso» del art. 5.3 RBI (art. 7.3 RBIbis) se refiere al mismo tiempo a la posible competencia de los tribunales del lugar donde se ha materializado el daño y a los del lugar donde se ha producido o ha tenido origen el hecho causal. La acción puede ejercitarse a elección del demandante ante cualquiera de los dos lugares (tal y como establece la Sentencia Coty Germany, asunto C-360/12, REDI, 2014-24-Pr, con nota de Desantes Real, M., pp. 258-262). Pero en esta ocasión el TJUE descarta la posibilidad de aplicar la segunda de las conexiones. Proyecta analógicamente la jurisprudencia vertida en la Sentencia Winstersteiger (asunto C-523/10, REDI, 2012-20-Pr, con nota de De Miguel Asensio, P., pp. 227-231) y despeja el significado de lugar de origen del hecho causal estableciendo que el hecho que genera la eventual vulneración de los derechos de autor a través de Internet, se debe a la conducta del propietario del sitio web (apdo. 24), al fin y al cabo, detonante «del proceso técnico consistente en enseñar las fotografías en Internet». De esta forma, concluye que el lugar donde se produce el hecho causal en el presente sería la sede de Energie Agentur y el tribunal competente el alemán y no el austriaco donde ha acudido la actora.

4. Descartada la aplicación del lugar de origen en aras a determinar la competencia del tribunal austriaco sólo nos queda acudir a la aplicación del lugar donde se ha materializado el daño. En este caso la materialización del daño es difusa y la viabilidad de que el daño se localice en un Estado distinto de aquél donde el demandado haya vulnerado los derechos de autor (colgando las fotografías en su sitio de Internet) se pone en entredicho (véase Oró MARTínez, C., «Lugar de producción del hecho dañoso cuando el demandado no ha actuado en el estado del foro: el caso de las acciones por infracción de derechos de autor», La Ley Unión Europea, septiembre 2014, núm. 18). El TJUE despeja la cuestión y avanzando un paso más en la interpretación del art. 7.3 del RBIbis, define qué debemos entender como «materialización del daño» en estos supuestos. Establece que no hace falta que el sitio de Internet controvertido se «dirija al Estado miembro donde se ha ejercitado la acción» y descarta la teoría de la focalización tal y como hiciera antes en la Sentencia Pinckney (véase DE Miguel Asensio, P., «Tribunales competentes en materia de infracciones de derechos patrimoniales de autor cometidas a través de Internet», La Ley-Unión Europea, 2014, núm. 11). Bajo estas circunstancias ha de considerarse que tanto la materialización del daño como el riesgo de dicha materialización se derivan de la posibilidad de acceder en el Estado miembro ante el que se ha ejercitado la acción a través del sitio de Internet a las fotografías amparadas por los Derechos esgrimidos (apdo. 34) asentando la teoría de la accesibilidad (criticada por Lopéz-TARUElla MARTínez, A., en Litigios transfronterizos sobre derechos de propiedad industrial e intelectual, Madrid, Dykinson, 2008, pp. 117 y ss.).

5. Una vez aclarada la competencia del tribunal austriaco como lugar de materialización del daño, todavía queda despejar si en su sede se podrá reclamar la totalidad del daño sufrido (tal y como pretende la autora) o únicamente por los daños producidos en ese territorio (como defiende el demandado). La solución parece depender de la extensión de la jurisprudencia asentada en las citadas sentencias eDate Advertising o en la Pinkney. En la primera se extrapolaba la jurisprudencia sobre los derechos de la personalidad de la Sentencia Shevill (asunto C-68/93) a los supuestos de violaciones 
cometidas a través de Internet, caracterizados por la «deslocalización del daño», y se añadía un criterio adicional que, en extensión del centro de intereses de la víctima, permitía reclamar en ese foro la totalidad del daño sufrido. Pero el asunto Pinkney no trata sobre los derechos de la personalidad sino sobre los derechos patrimoniales de autor; y éstos, al igual que los derechos de la propiedad industrial (asunto Wintersteiger), están sometidos al principio de territorialidad. De modo que el lugar donde se ha sufrido el daño es aquél donde está protegido el derecho patrimonial que se invoca y donde el daño puede materializarse. Y los tribunales de ese Estado van a ser competentes únicamente para conocer el daño causado en ese territorio.

6. En esta ocasión el TJUE parece inclinarse por aplicar lo estipulado en el asunto Pinckney y rechaza el argumento utilizado en eDate Advertising de aplicar el criterio de centro de intereses de la víctima extendiendo la reclamación a la totalidad del daño. De esta forma a pesar de atribuir la competencia a los tribunales del lugar de donde se materializa el daño, y por tanto del domicilio de la víctima, Austria, la limita al perjuicio producido en ese territorio. Ahora bien, la solución por la que se ha optado no está exenta de problemas. Tal y como establece el Abogado General P. Cruz Villalón, en sus Conclusiones Generales de 11 de septiembre de 2014, presenta grandes dificultades a la hora de cuantificar los daños producidos en ese Estado, en tanto la mera accesibilidad no ofrece indicios suficientes que nos permitan segmentar territorialmente los efectos de la violación.

\author{
Nerea Magallón Elósegui \\ Universidad de Deusto \\ http://dx.doi.org/10.17103/redi.67.2.2015.3b.02
}

2015-22-Pr

COMPETENCIA JUDICIAL INTERNACIONAL: RESPONSABILIDAD DEL EMISOR DE TÍTULOS DE DEUDA.--Reglamento 44/2001.-Contratos celebrados por los consumidores.-Adquisición de títulos emitidos por un banco establecido en otro Estado miembro, a través de un intermediario de un tercer Estado miembro.-Competencia para conocer de las acciones contra el banco emisor.

Preceptos aplicados: arts. 5.1.a), 5.3, y 15.1 del Reglamento 44/2001.

Sentencia del Tribunal de Justicia de 28 de enero de 2015, asunto C-375/13, Harald Kolassa y Barclays Bank plc. Ponente: M. Safjan.

\title{
F.: curia.europa.eu.
}

1) El artículo 15, apartado 1, del Reglamento (CE) n. ${ }^{\circ} 44 / 2001$ [...] debe interpretarse en el sentido de que, en circunstancias como las del litigio principal, el demandante que, como consumidor, ha adquirido un título de deuda al portador a un tercero profesional, sin que se haya celebrado un contrato entre dicho consumidor y el emisor de dicho título -lo que corresponde comprobar al tribunal remitente- no puede invocar la competencia establecida en esa disposición para interponer una acción frente a la entidad emisora del mencionado título de deuda basada en las condiciones del empréstito, en el incumplimiento de las obligaciones de información y de control y en la responsabilidad del folleto.

2) El artículo 5, punto 1, letra a), del Reglamento $n .{ }^{\circ}$ 44/2001 debe interpretarse en el sentido de que, en circunstancias como las del litigio principal, un demandante que ha adquirido un título de deuda al portador a un tercero, sin que su emisor haya asumido 
libremente una obligación frente a dicho demandante, lo que corresponde comprobar al tribunal remitente, no puede invocar la competencia establecida en esta disposición a los fines de la acción interpuesta contra el mencionado emisor basada en las condiciones del empréstito, en el incumplimiento de las obligaciones de información y de control y en la responsabilidad del folleto.

3) El artículo 5, punto 3, del Reglamento n. ${ }^{\circ} 4 / 2001$ debe interpretarse en el sentido de que se aplica a una acción que tiene por objeto que se declare la responsabilidad del emisor de un certificado por el folleto relativo a éste y por el incumplimiento de otras obligaciones jurídicas de información que incumben a dicho emisor, siempre que esta responsabilidad no esté incluida en la materia contractual, en el sentido del artículo 5, punto 1, de dicho Reglamento. En virtud del punto 3 del mismo artículo, los tribunales del domicilio del demandante son competentes, en razón de la materialización del daño, para conocer de tal acción, en particular, cuando el daño alegado se materializa directamente en una cuenta bancaria que el demandante tiene en un banco establecido en el territorio de estos tribunales.

Nota. 1. Aunque algunos instrumentos del Derecho de la UE han prestado en los últimos años atención a la regulación de los aspectos materiales de la responsabilidad derivada de la emisión de obligaciones en los mercados financieros, las cuestiones de Derecho internacional privado que las reclamaciones en ese ámbito pueden plantear se caracterizan por una particular complejidad acentuada por la ausencia en los instrumentos de la UE sobre competencia judicial y ley aplicable de reglas específicas sobre esa materia. En este contexto debe valorarse el interés de la sentencia reseñada. Sobre todo la Sentencia Kolassa resulta relevante en relación con la concreción del carácter no contractual de ciertas reclamaciones, la delimitación del alcance de las reglas específicas de protección de los consumidores, así como, muy especialmente, la localización del lugar del daño como criterio atributivo de competencia en el marco del (ahora) art. 7.2 Reglamento Bruselas I bis.

2. En síntesis, el litigio en el marco del cual se plantea la cuestión prejudicial va referido a la demanda interpuesta por un consumidor domiciliado en Austria que había invertido cierta cantidad de dinero en certificados emitidos por un banco domiciliado en el Reino Unido, como consecuencia de la pérdida de valor de los certificados. Ese Banco había difundido el folleto de la emisión también en Austria. Los certificados como títulos de deuda al portador se vendieron por el Banco a inversores institucionales, los cuales, a su vez, los revendieron a consumidores como el demandante en el litigio principal. En concreto, el intermediario había cumplido la orden del inversor "en régimen de depósito fiduciario», de modo que había asumido en nombre propio y por cuenta del inversor la custodia de los certificados, por lo que el inversor «sólo podía reclamar la entrega de los certificados correspondientes a su parte en los activos de cobertura, entendiéndose que éstos no podían transmitirse a su favor» (apdo. 15 de la sentencia).

En tales circunstancias, el inversor optó por demandar ante los tribunales de su propio domicilio (Austria) al Banco emisor con sede en el Reino Unido. Las cuestiones planteadas al Tribunal de Justicia iban referidas precisamente a interpretar si los tribunales austriacos tienen competencia para conocer de la reclamación frente al emisor establecido en otro Estado miembro.

3. Un primer elemento de interés es el relativo a la negativa del Tribunal de Justicia a que tal competencia pueda fundarse en las reglas específicas de competencia en materia de contratos de consumo. El Tribunal reitera su jurisprudencia previa acerca 
de que la efectiva celebración de un contrato entre el profesional y el consumidor es un requisito imprescindible para que pueda operar esa regla de competencia. Entiende el Tribunal que en un caso como el del litigio principal no se ha celebrado un contrato entre el consumidor y el emisor de los títulos, para lo que no basta que haya una cadena de contratos en virtud de los cuales ciertos derechos y obligaciones del emisor puedan transmitirse al consumidor.

4. En segundo lugar, la Sentencia Kolassa rechaza también que el fuero especial en materia contractual (ahora, art. 7.1 RBIbis) resulte de aplicación en un supuesto como el del litigio principal. Si bien de acuerdo con su jurisprudencia previa la aplicación de esta norma no requiere que se haya celebrado un contrato entre las partes, sí que presupone «la determinación de una obligación jurídica libremente consentida por una persona respecto a otra y en la que se basa la acción del demandante» (apdo. 39). El Tribunal considera que no existe tal vínculo entre el emisor y el inversor que adquiere un título de deuda al portador a un tercero, como en el litigio principal. Por el contrario, en relación con otro tipo de situaciones en las que tal vínculo sí puede existir, sí sería aplicable el art. 7.1 del RBIbis (véase la STJ de 18 de mayo de 2013, C-228/11, Melzer, apdo. 37).

Ahora bien, el alcance de la postura adoptada por el Tribunal de Justicia sobre este particular puede resultar controvertido. En concreto, en el apdo. 6 de la Sentencia Kolassa el Tribunal menciona que no existe ningún contrato entre el banco y el inversor en el litigio principal «ya que (el inversor) no es el tenedor de los títulos de deuda» que conserva el intermediario, por lo que puede surgir la duda de si el vínculo exigido por el art. 7.1 sí puede existir en otras situaciones en las que el inversor no adquiere los títulos directamente del emisor pero si es tenedor de los títulos. En todo caso, del conjunto de la sentencia parece desprenderse que resulta determinante a tal efecto el que el inversor hubiera adquirido los títulos en el mercado secundario de un tercero distinto del emisor (en sentido similar, véase el apdo. 64 de las conclusiones del Abogado General Bot en el asunto C-366/13, Profit Investment, pendiente ante el Tribunal de Justicia, y del que cabe esperar precisiones relevantes en relación, entre otros aspectos, con la oponibilidad de las cláusulas de jurisdicción incluidas en folletos de emisión de títulos).

5. Excluida en el caso concreto la calificación contractual, el Tribunal reitera en la Sentencia Kolassa que la regla de competencia en materia de responsabilidad extracontractual presenta en este ámbito un carácter residual con respecto a la materia contractual, y afirma que «las acciones de responsabilidad contra un emisor a causa del folleto y del incumplimiento de otras obligaciones jurídicas de información a los inversores están incluidas en responsabilidad extracontractual del artículo 7.2 Reglamento Bruselas I bis tiene también la materia delictual y cuasidelictual, siempre que no estén cubiertas por el concepto de "materia contractual”...» (apdo. 44). Esta calificación en el marco del Reglamento Bruselas I bis es autónoma e independiente del carácter contractual o extracontractual que las acciones tengan en la legislación nacional aplicable.

Con respecto a la aplicación del mencionado art. 7.2 en las reclamaciones de daños derivadas del incumplimiento por el emisor de sus obligaciones relativas al folleto y la información a los inversores, la sentencia incluye aportaciones relevantes tanto sobre la concreción del lugar de origen del daño como del lugar del manifestación del daño, tras aclarar que, conforme a la jurisprudencia previa, a esos dos elementos hace referencia el art. 7.2 cuando emplea como conexión «el lugar donde se haya producido o pueda producirse el hecho dañoso». 
6. Del apdo. 53 de la sentencia se desprende que el lugar de origen del daño se localiza básicamente donde se adoptan (por el banco emisor) las decisiones relativas a las modalidades de inversión propuestas y a los contenidos de los folletos, o donde los folletos han sido redactados y distribuidos al inicio, que en el litigio principal sería el Estado del domicilio social del banco emisor. De modo que en el caso concreto este criterio resulta de nula utilidad en la medida en que los tribunales de ese país son ya competentes con carácter general con base en el fuero del domicilio del demandado (art. 4 RBIbis).

7. Por su parte, el lugar de manifestación del daño se localiza dónde lo sufre el inversor y, para concretar éste, el Tribunal complementa el criterio ya establecido en su Sentencia Kronhofer, afirmando ahora que los «tribunales del domicilio del demandante son competentes, en razón de la materialización del daño, para conocer de tal acción, en particular, cuando el mencionado daño se produce directamente en una cuenta bancaria del demandante en un banco establecido en el territorio de esos tribunales» (apdo. 55). Cabe recordar que en su Sentencia de 10 de junio de 2004, C-168/02, Kronhofer (apdo. 21), el Tribunal había concluido que el lugar de manifestación del daño: "No comprende el lugar del domicilio del demandante en el que se localice el "centro de su patrimonio", sólo por el hecho de que el demandante haya sufrido en ese lugar un perjuicio económico como consecuencia de la pérdida de una parte de ese patrimonio acaecida y sufrida en otro Estado contratante». Ahora bien, cuando el daño se materializa directamente en una cuenta del demandante situada en el Estado miembro en el que tiene su domicilio, el art. 7.2 sí permite demandar al inversor ante los tribunales de su domicilio, destacando que en tales circunstancias es previsible para el demandado "dado que el emisor de un certificado que no cumple sus obligaciones legales relativas al folleto, cuando decide que se difunda el folleto relativo a este certificado en otros Estados miembros, debe esperar que inversores insuficientemente informados, domiciliados en otros Estados miembros, inviertan en este certificado y sufran el daño» (apdo. 56 Sentencia Kolassa). No obstante, los apdos. 55 y 57 y el fallo (punto 3) de la sentencia no hacen referencia a la vinculación entre la localización de la cuenta bancaria en la que se materializa directamente el daño y el lugar (o lugares) en los que el emisor decide que se difunda el folleto.

8. Para concluir, cabe reseñar que si bien algunos de los planteamientos adoptados en esta sentencia pueden resultar también relevantes al abordar las cuestiones de determinación de la ley aplicable, por ejemplo, en relación con la delimitación entre el Reglamento Roma I y el Reglamento Roma II, lo cierto es que la aplicación de este último a este tipo de reclamaciones resulta, como es bien conocido, fuente de controversia ante la ausencia de reglas específicas. En este sentido la mera proyección de la interpretación del lugar del daño que prevalece en la interpretación del art. 7.2 RBIbis a las normas sobre ley aplicable (en especial, al art. 4.1 Reglamento Roma II) podría conducir a un resultado inapropiado.

Pedro Alberto De Miguel Asensio Universidad Complutense de Madrid http://dx.doi.org/10.17103/redi.67.2.2015.3b.03

2015-23-Pr

COOPERACIÓN JUDICIAL EN MATERIA CIVIL.-Reglamento 44/2001.—Cláusula atributiva de competencia judicial del art. 23 del Reglamento 44/2001: forma.-Transmisión efectuada por medios electrónicos proporcionando un registro duradero del acuerdo.-Consulta e impresión de las condiciones generales 
de contratación desde un enlace que permite visualizarlas en una nueva ventana.-Técnica de aceptación mediante un clic (click-wrapping).

Preceptos aplicados: art. 23 del Reglamento 44/2001.

Sentencia del Tribunal de Justicia de 21 de mayo de 2015, asunto C-322/14, Jaouad El Majdoub v. CarsOnTheWeb.Deutschland GmbH. Ponente: C. Toader.

\section{F.: curia.europa.eu.}

El art. 23.2 R. 44 [...] debe interpretarse en el sentido de que la técnica de aceptación mediante un "clic» de las condiciones generales, que incluyen una cláusula atributiva de competencia, de un contrato de compraventa celebrado por vía electrónica, como el del litigio principal, constituye una transmisión por medios electrónicos que proporciona un registro duradero de dicha cláusula, en el sentido de esta disposición, siempre que esa técnica permita imprimir y guardar el texto de las citadas condiciones antes de la celebración del contrato.

Nota. 1. El Sr. El Majdoub, concesionario de automóviles domiciliado en Colonia (Alemania) y demandante en el litigio principal, adquirió en el sitio web propiedad de la demandada CarsOn The Web.Deutschland GmbH, domiciliada en Amberg (Alemania), un automóvil eléctrico a buen precio. Cancelada la venta por el vendedor, El Majdoub reclamó la cesión de la propiedad del vehículo ante el Landgericht Krefeld, dado el domicilio en Alemania de CarsOn y no ante los Tribunales belgas aun cuando la domiciliación en Bélgica de su sociedad matriz. CarsOn entiende la no competencia de los Tribunales alemanes y sí de los belgas: se basa, además de por haber solicitado el comprador a la sociedad matriz belga la emisión de una factura sin el IVA o por haber pagado el precio del automóvil a través de una cuenta belga, en la existencia de una cláusula de sumisión expresa a favor de un Tribunal de Lovaina (Bélgica) contenida en las condiciones generales de contratación (art. 7) de una operación realizada por Internet, accesibles desde su sitio web. El Majdoub considera que el acuerdo atributivo de competencia de ese art. 7 no se ajusta al art. 23.1.a) del Reglamento 44/2001 (RBI) al no incorporarse válidamente al contrato de compraventa por no celebrarse por escrito, dado que la página web de CarsOn, que contiene sus condiciones generales de contratación, no se abre automáticamente con el registro ni con cada compra, sino que es necesario seleccionar una casilla con la indicación Hacer clic aquí para acceder a las condiciones generales de entrega y pago en una nueva ventana (técnica de aceptación mediante un clic o click-wrapping). Dado que está en juego su competencia, el órgano jurisdiccional remitente cuestiona si esta técnica en la que el texto de las condiciones generales no se abre automáticamente con el registro en el sitio web ni cuando se efectúa una transacción, sino tras un clic, que remite a una página distinta, donde la contraparte contractual sí tiene la posibilidad de imprimirlo o guardarlo, se ajusta a las exigencias del art. 23.2 del RBI, esto es, a una transmisión efectuada por medios electrónicos que proporcione un registro duradero del acuerdo y, por consiguiente, por escrito.

2. Al derogar la competencia general del art. 2 del RBI y especial de los arts. 5-7 del RBI, debe interpretarse de manera estricta un art. 23 del RBI (con más razón, el art. 25 del Reglamento 1215/2012, al eliminar las exigencias espaciales de domiciliación de cualquiera de las partes) que habla, como es sabido, de la competencia exclusiva (mejor, única, ex art. 17 del CB de 1968) de aquellos Tribunales comunitarios seleccionados a través del ejercicio de la autonomía de la voluntad de las partes (apdo. 14 
de la STJCE de 20 de febrero de 1997, MSG). Subordinar la validez de una cláusula atributiva de competencia a la existencia de un acuerdo (apdo. 26 de la STJUE de 7 de febrero de 2013, Refcomp), pasa por verificar si esa cláusula nace efectivamente de un consentimiento manifestado de manera clara y precisa por las partes: las exigencias de forma del art. 23 del RBI no tienen otra función que garantizar la prueba efectiva de la existencia de este consentimiento (apdo. 15 de la citada Sentencia $M S G$ ), que la irrupción de Internet y las nuevas tecnologías no hace sino complicar, obligando al legislador no sólo a adaptar sus normas (art. 1.10 de los Principios UNIDROIT sobre contratos comerciales internacionales; internamente, art. 23 de la Ley 34/2002, de 11 de julio, de servicios de la sociedad de la información y de comercio electrónico...), tal como sucede con el art. 23.2 del RBI (y 25.2 del Reglamento 1215/2012; punto ausente en el anterior art. 17 del CB de 1968), sino también a valorar la compatibilidad de su tenor con las nuevas técnicas de comunicación, esta vez con la técnica de aceptación mediante un clic o click-wrapping. Aunque en el caso que nos ocupa se plantea si esta técnica responde a la idea de transmisión efectuada por medios electrónicos que proporcione un registro duradero del acuerdo, y, por tanto, equivalente a por escrito, lo cierto es que la validez formal de las cláusulas de elección de foro por medios electrónicos no va a depender en muchas ocasiones de la consideración como por escrito de la transmisión sino de su adecuación a los hábitos establecidos entre las partes o, en el comercio internacional, a los usos que las partes conozcan o deban conocer [art. 23.1.b) y c) del RBI].

3. Aunque sí pueden ser importantes para hacer prueba de su existencia, ni el RBI ni el Reglamento 1215/2012 exigen formalidades especiales, como la utilización del sistema de firma electrónica, a la hora de considerar un acuerdo como celebrado por escrito: la finalidad del art. 23.2 del RBI al considerar hecha por escrito la transmisión efectuada por medios electrónicos que proporcione un registro duradero del acuerdo es asimilar a la forma escrita, en orden a simplificar la celebración de contratos por medios electrónicos, determinadas modalidades de transmisión electrónica (FD 36). Para cumplir esta exigencia basta con que la información en la que consta el pacto de sumisión expresa se contenga en un soporte que posibilite su posterior consulta al poder ser archivado electrónicamente o trasladado al papel a través de su impresión, tal como sucede cuando la contratación se formaliza mediante el intercambio de mensajes de correo electrónico o por el contacto interactivo con una página web (DE MIGUEL Asensio, P., Derecho privado de Internet, Navarra, 5. ${ }^{\text {a }}$ ed., Thomson-Civitas, 2015, p. 1014). Es lo que aquí sucede cuando el comprador en el asunto principal, antes de efectuar su compra, aceptó de forma expresa las condiciones generales en cuestión, en las que figuraba el pacto de elección de foro, marcando la casilla correspondiente en el sitio web del vendedor; y ello, aun cuando esta operación no suponía la apertura automática del documento que las contenía, lo que exigía hacer otro clic en un hipervínculo específico previsto para ello, esto es, aun cuando la ventana que mostraba las condiciones generales no se abría automáticamente con el registro en el sitio web ni cuando se efectuaba una operación de compra o cualquier otra transacción.

La realidad del consentimiento de los interesados, objetivo del art. 23 del RBI, no pasa necesariamente por el hecho de que el registro del acuerdo se haya creado de hecho, sino sólo que la página web conceda a las partes la posibilidad de proceder a su registro de forma duradera (FD 32), esto es, lo que hace la norma es exigir la posibilidad de registrar el acuerdo atributivo de competencia de forma duradera, independientemente de si el texto de las condiciones generales fue efectivamente registrado por el comprador, antes o después de marcar la casilla indicando que acepta las referidas condiciones (FD 33). O, lo que es lo mismo, la intención del art. 23 del RBI es 
que la exigencia de un acuerdo escrito o de un acuerdo verbal con confirmación escrita no cuestione la validez de una cláusula de elección del foro convenida en un soporte no escrito pero cuyo contenido sea accesible a través de una pantalla [Exposición de Motivos de la Propuesta de Reglamento (CE) del Consejo sobre la competencia judicial, el reconocimiento y la ejecución de resoluciones judiciales en materia civil y mercantil, presentada por la Comisión el 14 de julio de 1999, COM(1999) 348 final]: en este sentido, y siguiendo esta interpretación histórica y teleológica del art. 23.2 del RBI, pueden entenderse cumplidos los requisitos formales del art. 23.1 del RBI en tanto que sea «posible crear un registro duradero de una comunicación electrónica imprimiéndola o salvando una copia en cinta o en disco o almacenándola de cualquier otra forma [...]; [y ello], [...] aunque ese registro duradero no se haya creado de hecho [...] [de manera que] [...] el registro no se exigirá como condición necesaria para la validez formal o la existencia de la cláusula» (PocAR, F., Informe al Convenio de Lugano de 30/7/07 relativo a la competencia judicial, reconocimiento y ejecución de resoluciones judiciales en materia civil y mercantil, apdo. 109). En consecuencia, dado que los datos también se transmiten en caso de que se pueda acceder a ellos a través de una pantalla, basta, como es el caso, con que sea posible guardar e imprimir la información antes de la celebración del contrato, aspecto que, por otra parte, no se cuestiona en tanto que la técnica de aceptación mediante un clic o click-wrapping permite imprimir y guardar el texto de las condiciones generales antes de la celebración del contrato (FD 39; también art. 7.4 de la Ley Modelo CNUDMI Arbitraje Comercial Internacional).

4. No se opone lo expuesto a la interpretación del TJUE de la exigencia del art. 5.1 de la Directiva 97/7/CE relativa a la protección de los consumidores en materia de contratos a distancia, de que el consumidor deberá «recibir» determinada información, "por escrito o mediante cualquier otro soporte duradero»: cuando el TJUE entiende que no puede considerarse soporte duradero, en tanto en cuanto que tal información no es ni facilitada por la empresa ni recibida por el consumidor, aquella práctica comercial consistente en dar acceso a la información sólo mediante un hipervínculo a un sitio de Internet (apdo. 51 de la STJUE de 5 de julio de 2012, Content Services), lo hace en el contexto de un art. 5.1 de la Directiva 97/7 presidido por un principio, la protección de los consumidores, que no está detrás del art. 25.2 del RBI (FFDD 37 y 38; ahora, art. 8 de la Directiva 2011/83/UE, de 25 de octubre de 2011, sobre los derechos de los consumidores, cuya nueva terminología puede hacer dudar del alcance de esta jurisprudencia; proyectándola, De Miguel Asensio, P., op. cit., p. 927).

Javier MASEDA RoDRíGUEZ

Universidad de Santiago de Compostela

http://dx.doi.org/10.17103/redi.67.2.2015.3b.04

2015-24-Pr

COMPETENCIA JUDICIAL INTERNACIONAL.-Reglamento 44/2001.-Infracción al art. 101 TFUE.-Acción indemnizatoria.-Foro alternativo en materia delictual y cuasi-delictual.

Preceptos aplicados: arts. 6.1, 5.3 y 23.1 del Reglamento 44/2001.

Sentencia del Tribunal de Justicia (Sala 4. ${ }^{\text {a }}$ ), de 21 de mayo de 2015, asunto C-352/13, Cartel Damage Claims (CDC) Hydrogen Peroxide SA c. Akzo Nobel NV y otros. Ponente: M. Safjan.

\section{F.: curia.europa.eu.}


1) El artículo 6, punto 1, del Reglamento (CE) n. 44/2001 [...] debe interpretarse en el sentido de que la regla de concentración de competencias en caso de pluralidad de demandados que esa disposición establece puede aplicarse en el supuesto de una acción para la condena solidaria al pago de una indemnización y para la presentación de informaciones, [...] y ello incluso si el demandante ha desistido de su acción frente al único codemandado domiciliado en el Estado miembro del tribunal que conoce del asunto, a menos que se acredite la existencia de una colusión entre el demandante y el referido codemandado para crear o mantener de forma artificial las condiciones de aplicación de esa disposición en el momento de ejercitarse la acción.

2) El artículo 5, punto 3, del Reglamento $n .^{\circ} 44 / 2001$ debe interpretarse en el sentido de que, cuando se reclama judicialmente una indemnización a demandados domiciliados en diferentes Estados miembros [...] cada una de [las] víctimas puede elegir entre ejercer su acción ante el tribunal del lugar en el que fue definitivamente constituido el cártel, o del lugar en el que en su caso fue concluido un arreglo específico e identificable por sí solo como el hecho causal del perjuicio alegado, o bien ante el tribunal del lugar de su propio domicilio social.

3) El artículo 23, apartado 1, del Reglamento n. ${ }^{\circ} 44 / 2001$ debe interpretarse en el sentido de que, [...] permite tener en cuenta las cláusulas atributivas de competencia contenidas en contratos de suministro, incluso cuando su efecto sea excluir las reglas de competencia internacional previstas en los artículos 5, punto 3, y/o 6, punto 1, de ese Reglamento, siempre que esas cláusulas se refieran a las controversias sobre la responsabilidad incurrida a causa de una infracción del Derecho de la competencia.

Nota. 1. La sentencia que aquí se comenta es la primera en pronunciarse sobre la articulación de las disposiciones de Derecho internacional privado europeo con el Derecho de la competencia. Siendo varias las cuestiones resueltas, este comentario incidirá en la concreción del foro del art. 5.3 del Reglamento 44/2001 (en adelante, RBI, que ha sido sustituido por el Reglamento 1215/2012) elaborada por el Tribunal de Justicia (en adelante, TJ) en materia de prácticas concertadas (infra 5). Analizaremos también las complejidades que conlleva la aplicación de esta norma en el asunto principal. Previamente expondremos los hechos del caso, la solución del TJ (infra 2 y 3) y haremos una valoración general de la decisión (infra 4).

2. Evonik Degussa —el demandado principal — junto con varias empresas, formaron el cártel de peróxido de hidrógeno en 1994. Hasta los años 2000, cometieron una violación única y continuada de los arts. 81 CE [101 TFUE] y $53 \mathrm{EEE}$, finalmente sancionada por la Comisión Europea. En marzo de 2009, Cartel Damage Claims (en adelante, CDC), una sociedad belga cesionaria de las acciones de treinta y dos demandantes procedentes de distintos Estados miembros, demandó a Evonik Degussa y al resto de infractores ante un tribunal de Dortmund (Alemania) con el fin de obtener la reparación del daño resultante del incremento en el precio de las mercancías comercializadas por los miembros del cártel. Posteriormente, CDC llegó a un acuerdo con Evonik Degussa, y desistió de su demanda. Por su parte, los demás demandados impugnaron la competencia de los tribunales alemanes, invocando la existencia de acuerdos de elección de foro o cláusulas arbitrales. A raíz de estas consideraciones, el tribunal remitente pregunta, por una parte, si puede fundamentar su competencia en los arts. 6.1 o 5.3 del RBI y por otra, si las cláusulas atributivas de competencia (art. 23 del RBI) y de arbitraje concluidas entre las partes distorsionan las reglas de competencia judicial aplicables al caso concreto.

3. La primera tarea que aborda el TJ consiste en determinar si el art. 6.1 del RBI permite atraer a los miembros de un cártel al foro del domicilio de uno de los 
demandados. El TJ responde afirmativamente porque, por los vínculos que atan a los cartelistas, interponer demandas separadas podría generar resoluciones inconciliables. El TJ confirma que la competencia judicial adquirida según el art. 6.1 del RBI no desaparece si se produce desistimiento de la demanda frente al demandado principal, salvo que los demandantes hayan creado las condiciones para que se aplique tal norma y así, evitar la competencia de otros tribunales. En este caso, el TJ concluye que no existen elementos probatorios suficientes que permitan afirmar el comportamiento conspirativo de las partes. Seguidamente, el TJ analiza la aplicación del art. 5.3 del RBI, destacando que, conforme a esta norma, cada uno de los demandantes puede interponer su demanda alternativamente: 1) ante los tribunales del lugar en el que se constituyó el cártel; 2) ante los tribunales del lugar donde se concluyó un acuerdo generador de daños; 3 ) o ante los del lugar en el que se manifestaron los daños que corresponderá, en principio, al domicilio social de la víctima. Por último, el TJ considera que las cláusulas atributivas de competencia y arbitrales se aplican a las relaciones entre las partes del asunto principal.

4. La correcta interpretación del TJ respeta el tenor de las reglas vigentes de Derecho internacional privado. Concretamente, la atracción de los participantes de un cártel al foro del domicilio del demandado principal es coherente con la línea jurisprudencial establecida hasta ahora (STJCE C-103/05, Reisch Montage AG c. Kiesel Baumaschinen Handels GmbH; STJCE C-98/06, Freeport plc c. Olle Arnoldsson). También es acertado el razonamiento del Tribunal acerca del art. 23 del RBI, pues respeta el principio de la autonomía de la voluntad. Según éste, los acuerdos atributivos de competencia o arbitrales se tendrán en consideración si su tenor engloba controversias resultantes de un ilícito concurrencial. Más dudosa, por el contrario, es su interpretación del art. 5.3 del RBI: el TJ precisa cuáles son los foros incluidos en el ámbito del art. 5.3 del RBI pero silencia las dificultades prácticas que plantea la aplicación de esta norma a un caso de Derecho de la competencia, y esto a pesar de las preocupaciones expresadas por el Abogado General en sus conclusiones (apdos. 7-10). En esta tesitura, tal vez hubiera sido oportuno que el TJ explicase su decisión de concretar el foro del art. 5.3 del RBI como lo hizo y aclarara su elección de apartarse de la opinión del Abogado General en cuanto a la aplicación de esta misma norma.

5. La delimitación del foro del art. 5.3 del RBI en materia de prácticas concertadas ciertamente pone fin a las numerosas dudas que han surgido alrededor de esta cuestión. Sin embargo, desde un punto de vista práctico, la aplicación de esta norma sigue siendo problemática. Para empezar, el lugar de conclusión de un cártel o de un acuerdo ilícito específico (Handlungsort) parece ser un foro adecuado, ya que concuerda con la jurisprudencia Shevill (C-68/93, Fiona Shevill y otros c. Presse Alliance SA) y está respaldado por la doctrina [DANov, M., Jurisdiction and Judgments in Relation to EU Competition Law Claims, Oxford, Hart Publishing, 2011, pp. 92-94; BASEDOW, J., «International cartel and the place of acting under 5(3) of the Brussels I Regulation», en BASEDOw, J. et al. (coords.), International antitrust litigation, Oxford, Hart Publishing, 2012, pp. 33-34]. A pesar de ello, cabe señalar que este foro es de difícil concreción debido a la naturaleza secreta de los acuerdos de los miembros de un cártel. Además, en este lugar sólo se pueden reclamar los daños que estén causalmente vinculados con el hecho generador. Por consiguiente, el foro pierde su utilidad si se identifica una multitud de actos ilícitos cometidos en lugares distintos. Subrayamos que la dispersión geográfica de las violaciones al Derecho de la Unión entorpece sobremanera la acumulación de los procedimientos judiciales en un foro único, como pretende CDC. Resulta conveniente señalar también que el TJ no ha retenido el lugar de implementación del acuerdo ilícito como foro válido del art. 5.3 del RBI y esto, a 
pesar de las razonables sugerencias doctrinales que apoyan esta interpretación con base en el caso Ashlström (asuntos acumulados C-89, 104, 114, 116, 117, 125-129/85, Ahlström Osakeyhtiö y otros c. Comisión, donde el TJ distingue entre la conclusión del acuerdo colusorio y su ejecución). Esta omisión puede justificarse porque resulta arduo identificar el lugar concreto de implementación del acuerdo: ¿deberíamos considerar que se trata del lugar del domicilio del infractor porque allí se concretan las decisiones de restricción al Derecho de la competencia con respecto a un mercado determinado? o ¿debería este lugar corresponder al lugar de conclusión de los contratos de compraventa porque allí se produce el daño resultante del incremento en los precios?

En cuanto al lugar de materialización del daño (Erfolgsort), el TJ aclara que este lugar corresponderá en principio con el domicilio social de la víctima, lo que facilita la identificación del tribunal competente. Este razonamiento parece lógico porque es el lugar donde se resiente la pérdida económica resultante del control de los precios por parte de los cartelistas. Sin embargo, el lugar de la conclusión o ejecución del contrato de compraventa y el lugar de implementación del acuerdo ilícito son lugares igualmente válidos y vinculados con la infracción que el Tribunal hubiera podido considerar. En todo caso, el lugar de materialización del daño pierde su atractivo en caso de que los demandantes quieran unificar sus demandas debido a las limitaciones jurisdiccionales del tribunal de este foro. De todo esto se desprende que tanto las complejidades fácticas de la infracción como la del asunto principal como las restricciones territoriales del art. 5.3 del RBI obstaculizan la correcta aplicación de esta norma.

6. En conclusión, aunque valoramos positivamente la concreción del foro del art. 5.3 del RBI, el TJ deja importantes cuestiones abiertas como el desajuste del art. 5.3 del RBI y el Derecho de la competencia, lo que dificulta la apertura de un verdadero foro alternativo en materia delictual y, por tanto, debilita el derecho a la tutela judicial efectiva en particular para los demandantes que desean acumular acciones indemnizatorias resultante de una infracción al Derecho de la competencia. Afortunadamente, la posibilidad de recurrir al art. 6.1 del RBI matiza esta conclusión.

Alexia PATO

Universidad Autónoma de Madrid

http://dx.doi.org/10.17103/redi.67.2.2015.3b.05

\subsection{Competencia judicial internacional en materia de responsabilidad parental}

2015-25-Pr

RESPONSABILIDAD PARENTAL.-Prórroga de la competencia.-Aceptación de la competencia.-Alcance de la prórroga.-Inexistencia de proceso conexo.

Precepto aplicado: art. 12.3 del Reglamento (CE) núm. 2201/2003 (Bruselas II bis).

Caso 1. Sentencia del Tribunal de Justicia (Sala 2. ${ }^{a}$ ) de 1 de octubre de 2014, asunto C-436/13, E. y B. Ponente: A. Arabadjiev.

F.: curia.europa.eu.

La competencia en materia de responsabilidad parental, prorrogada, en virtud del artículo 12, apartado 3, del Reglamento (CE) n. ${ }^{\circ} 2201 / 2003$ [...] en favor de un órga- 
no jurisdiccional de un Estado miembro ante quien los titulares de la responsabilidad parental han incoado de común acuerdo un procedimiento, se extingue al recaer una resolución firme en el marco de dicho procedimiento.

Caso 2. Sentencia del Tribunal de Justicia (Sala $3 .^{a}$ ) de 11 de noviembre de 2014, asunto C-656/13, L. y M. Ponente: E. Jarašiūnas.

\section{F.: curia.europa.eu.}

1) El art. 12, apartado 3, del Reglamento (CE) n. ${ }^{\circ} 2201 / 2003$ [...] debe interpretarse en el sentido de que, en el caso de un procedimiento en materia de responsabilidad parental, dicha disposición permite fundamentar la competencia de un tribunal de un Estado miembro que no es el de la residencia habitual del menor, aun cuando no exista ningún otro procedimiento pendiente ante el tribunal elegido.

2) El art. 12, apartado 3, letra b), del Reglamento $n .^{\circ} 2201 / 2003$ debe interpretarse en el sentido de que no puede considerarse que la competencia del tribunal ente el que una parte insta la sustanciación de un procedimiento en materia de responsabilidad parental ha sido "aceptada expresamente o de cualquier otra forma inequivoca por todas las partes en el procedimiento", a efectos de dicha disposición, cuando la parte demandada en este primer procedimiento inicie posteriormente un segundo procedimiento ante el mismo tribunal y alegue, con ocasión de la primera actuación que le incumba en el primer procedimiento, la incompetencia del tribunal.

Nota. 1. El art. 12.3 del Reglamento Bruselas II bis constituye una norma singular en el ámbito de la competencia judicial internacional sobre responsabilidad parental, sin parangón en sus antecedentes convencionales (los Convenios de La Haya de 1961 y de 1996). Permite un espacio para la autonomía de la voluntad en la determinación de la competencia aunque no es su finalidad esencial garantizar la libertad de elección de los tribunales por las partes, criterio que no está presente, como tal, ni en estos litigios ni en otros vinculados a menores, como los procesos sobre alimentos [art. 4.3 del Reglamento (CE) núm. 4/2009]. No se trata, en efecto, de establecer un criterio de competencia basado en la sumisión de las partes al modo conocido en Bruselas I bis, sino de justificar la competencia de unos tribunales por razones de economía procesal (art. 12.1) o de proximidad (art. 12.3), al margen del criterio general de la residencia habitual del menor (ANDRAE, M., «Erste Entscheidungen des EuGH zu Art. 12 Abs. 3 EuEheVO», IPRax., 2015, pp. 212 y ss., esp. p. 214). Los supuestos de vinculación establecidos en el art. 12.3.a) (residencia habitual de uno de los titulares de la responsabilidad parental o nacionalidad del menor) constituyen un numerus apertus, que no impedirá la valoración de otros supuestos (por ejemplo, una residencia habitual anterior del menor en el Estado). En todo caso, la expresa mención del criterio de la nacionalidad del menor permitirá rescatar, de alguna manera, la competencia de las autoridades de la nacionalidad en la estela del art. 4 del Convenio de La Haya de 1961 [RAuscher, T. (coord.), Europäisches Zivilprozess- und Kollisionsrecht EuZPPR/EuIPR, Münich, Sellier, 2010, p. 180].

Las dos Sentencias del Tribunal de Justicia objeto de este comentario inciden en algunos aspectos de funcionamiento de este criterio de la prórroga de competencia. En el asunto $E$. y $B$. se trata de determinar el alcance de la competencia del tribunal cuya competencia fue acordada. Básicamente, debía dilucidarse la posibilidad de que el Juzgado de 1. a Instancia de Torrox (Málaga), que había dictado una resolución ratificando un acuerdo entre las partes sobre responsabilidad parental, fuera también 
competente para un proceso posterior, en el que la madre pretendía una revisión de dicho acuerdo, en un momento en que ya el menor tenía nueva residencia habitual en el Reino Unido. En el asunto L. y M., el Tribunal de Justicia se pronuncia sobre los requisitos exigibles para entender prorrogada la competencia y el alcance de esta prórroga cuando el litigio versa exclusivamente sobre medidas de responsabilidad parental, sin vinculación a otro proceso conexo. Del contenido de estas sentencias pueden derivarse varios condicionantes que deberán ser considerados al interpretar y aplicar el art. 12.3 del Reglamento Bruselas II bis.

2. El primer condicionante versa sobre los requisitos de la aceptación de la competencia. De la literalidad del art. 12.3 se deriva que dicha aceptación tiene que producirse en el momento de presentar el asunto ante el órgano jurisdiccional y tiene que ser «aceptada expresamente o de cualquier otra forma inequívoca por todas las partes en el procedimiento".

La fijación del momento de la aceptación, en el inicio del procedimiento en los términos establecidos en el art. 16 del Reglamento, sirve para delimitar el carácter de la sumisión. Por una parte, queda claramente excluida la sumisión expresa pactada previamente a un proceso (ANDRAE, M., op. cit., p. 214), dado que dicho acuerdo sólo será posible, en su caso, una vez abierto el proceso. Por otra parte, se exige una inmediación en la aceptación de dicha competencia.

En cuanto a las conductas procesales que evidencien la aceptación de la competencia, el supuesto será claro cuando las partes expresamente la reconozcan. Más dudas se suscitan en relación con una aceptación basada en «cualquier otra forma inequívoca», que permite un margen de apreciación sobre la voluntad real de las partes en el proceso. En todo caso, se entiende exigible el principio de especialidad en la aceptación, esto es, que deba realizarse en relación con «el proceso concreto» abierto ante ese tribunal.

Estos contornos, definidos por el TJUE en el asunto L. y $M$., son utilizados para considerar que en el asunto de referencia no se había producido dicha prórroga de competencia. En esencia, el problema se planteaba en torno a la valoración y las consecuencias del comportamiento procesal de la madre: existía una primera demanda, de 26 de octubre de 2012, presentada por el padre ante un tribunal checo; la madre, tan sólo tres días más tarde (el 29 de octubre de 2012), presenta una nueva demanda ante el mismo tribunal y con el mismo objeto; posteriormente, impugna la competencia de los tribunales checos por considerar competentes a los tribunales austríacos, correspondientes a la nueva residencia habitual de los menores.

Analizado aisladamente el comportamiento procesal de la madre cuando demanda ante los tribunales checos, podría derivarse una voluntad real de aceptación de la competencia de esos tribunales. No cabe cuestionar la falta de inmediación, cuando tan sólo habían transcurrido tres días desde la presentación de la demanda interpuesta por el padre. La ulterior impugnación de la competencia por la madre, en contra de sus propios actos, y los motivos aducidos para justificar su conducta (supuestamente obtener información sobre los hijos) sólo evidencia una estrategia procesal equivocada que pretende corregir con posterioridad. Por ello, de una valoración conjunta de esta conducta cabría deducir que no ha habido una voluntad real de reconocer la competencia de los tribunales checos.

3. El segundo condicionante tiene que ver que con la duración temporal del criterio de competencia basado en el art. 12.3: la prórroga de la competencia se agota una vez que el tribunal aceptado por las partes haya dictado una resolución que haya 
devenido firme. En el asunto E. y B., esta limitación impedía, a juicio del TJUE, que

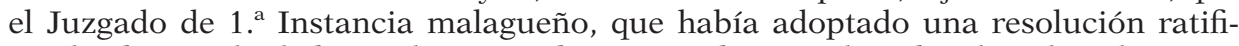
cando el acuerdo de los padres, en relación con la custodia y los derechos de visita, extendiese su competencia a la modificación de dicha resolución. Evidentemente, esta firmeza ha de entenderse como cosa juzgada formal, siendo, por tanto, válida la prórroga en relación con las diferentes instancias dentro de un mismo procedimiento. Lo que supone es que cualquier proceso posterior que se plantee para modificar resoluciones anteriores, basándose en un cambio de circunstancias, requerirá una nueva valoración sobre la competencia de los tribunales, sin que el acuerdo de voluntades anterior extienda sus efectos a este nuevo proceso. Como indica el TJUE ni cabe presumir una aceptación de la competencia de estos tribunales con efectos vinculantes ilimitados, ni cabe presumir de manera indefinida que dicha competencia corresponde al interés superior del menor en el sentido exigido por el art. 12.3 (asunto E. y $B$., apdo. 46).

En realidad, la evaluación de la competencia para cada proceso en concreto es una característica de los foros en materia de responsabilidad parental del Reglamento. La regla general es que no se prolonga la competencia de los tribunales que han dictado una resolución sobre una eventual modificación posterior de dicha resolución, dejando al margen el supuesto de modificación del derecho de visita cumplidas las condiciones establecidas en el art. 9. La fecha crítica viene establecida por la presentación de la demanda (art. 16 en relación con los arts. 8.1 y 12) momento en que habrá de verificarse, en cada caso, el cumplimiento de las circunstancias exigidas para justificar el foro de competencia (el acuerdo de voluntades, la residencia habitual del menor, etc.).

4. El tercer condicionante (cabría más bien decir, no condicionante) implica que no es necesario, para que opere la prórroga de la competencia, que exista un procedimiento conexo pendiente ante ese tribunal. El TJUE despeja de este modo las dudas derivadas de un tenor literal del art. 12.3 de interpretación incierta (los tribunales «tendrán igualmente competencia en materia de responsabilidad parental en procedimientos distintos de los contemplados en el apartado $1 »)$. Entre las diversas opciones interpretativas, el TJUE opta por la más amplia: entiende aplicable el art. 12.3 respecto de procesos que versen exclusivamente sobre la responsabilidad parental, sin ser accesorios o dependientes de otros litigios ante esos tribunales. Tal conclusión puede compartirse en la medida en que favorece el margen de actuación de la autonomía de la voluntad para los litigios de responsabilidad parental; no convence, sin embargo, la fundamentación utilizada por el Tribunal de Justicia, basada en la igualdad de los hijos, matrimoniales y no matrimoniales. Ciertamente, la interpretación alternativa del art. 12.3 que ofrece el TJUE podría impedir totalmente el funcionamiento de la prórroga de competencia sobre litigios en relación con hijos no matrimoniales. A tal resultado se llegaría, en efecto, si se considerara que el art. 12.3 sólo operaría a favor de tribunales que estuvieran conociendo de un proceso matrimonial basado en criterios de competencia del Derecho autónomo (art. 7 en relación con la literalidad del arts. 12.1 y 12.3). Pero otra interpretación sería igualmente posible sin llegar a ese efecto no deseado: cabría considerar, por ejemplo, que la prórroga de competencia sólo podría producirse a favor de tribunales que estuvieran conociendo de otro proceso conectado con la responsabilidad parental, por ejemplo, alimentos (véase PAtaut, E., en Magnus, U. y Mankowski, P., Brusells II bis Regulation, Múnich, Sellier, 2012, p. 156). Más interesante, para justificar la interpretación amplia del art. 12.3, es la finalidad de potenciar la autonomía de la voluntad a favor de tribunales sólo por el hecho de estar estrechamente vinculados con el menor, con base en conexiones (como 
la nacionalidad o una residencia habitual anterior) desechadas por el Reglamento como foros principales de competencia.

Se ha advertido, que esta interpretación amplia del art. 12.3 puede tener la consecuencia de vaciar de contenido el art. 15 (ANCEL, B., "L'intérêt supérieur de l'enfant dans le concert des juridictions: le Rêglement Bruxelles II bis», Rev. crit. dr. int. priv. 2005, p. 588), cuestión también evidenciada por el TJUE. Siendo esencialmente coincidentes los presupuestos sustentadores de la competencia en ambos supuestos (vinculación estrecha y competencia en interés del menor), la balanza entre estos dos preceptos debería inclinarse a favor del foro del art. 12.3. Para que se planteara la hipótesis del eventual juego del art. 15 tendría que ocurrir que el tribunal remitente fuera competente con base en el art. 12.3. La competencia basada en el art. 12.3 significa, en los términos indicados, una aceptación por todas las partes de esa competencia y, además, la existencia de un proceso pendiente sobre el que no haya recaído una resolución firme. Teniendo esto en cuenta, resultaría difícilmente sostenible que ese tribunal transfiriera la competencia a otros tribunales basándose en un forum non conveniens. Difícilmente tendría cabida una remisión a instancia de parte [en el sentido del art. 15.2.a)] si consideramos que ambas partes aceptaron la competencia del tribunal potencialmente remitente. Pero tampoco resultaría fácilmente justificable una remisión de oficio por el tribunal, desviando el proceso a otros tribunales en contra de la voluntad de las partes.

5. En definitiva, el Tribunal de Justicia ha sentado algunas pautas interpretativas de un criterio de competencia novedoso en el ámbito de la responsabilidad parental, que abre la puerta, siquiera tímidamente, a la autonomía de la voluntad en este tipo de litigios. La tendencia marcada apunta al rigor en la determinación de la aceptación de la competencia pero también a la flexibilidad en su funcionamiento en relación con litigios que versen en exclusiva sobre dicha responsabilidad parental.

\author{
Pilar JimÉNEZ BLANCO \\ Universidad de Oviedo \\ http://dx.doi.org/10.17103/redi.67.2.2015.3b.06
}

2015-26-Pr

TRASLADO ILÍCITO DE MENORES.-Cooperación judicial en materia civil.Reglamento (CE) núm. 2201/2003.—Art. 11, apartados 7 y 8.-Tribunal especializado para examinar las cuestiones relativas a la restitución.-Tribunal competente sobre el fondo de la responsabilidad parental.

Preceptos aplicados: arts. 3, 12 y 13 del Convenio de La Haya de 1980 sobre los aspectos civiles de la sustracción internacional de menores; arts. 1, 2, 8, 11 y 15 del Reglamento 2201/2003; art. 1322 del Código judicial belga.

Sentencia del Tribunal de Justicia (Sala $4 .^{\text {a }}$ ) de 9 de enero de 2015, asunto C-498/14, David Bradbrooke c. Anna Aleksandrowicz. Ponente: L. Bay Larsen.

\title{
F.: curia.europa.eu.
}

El artículo 11, apartados 7 y 8, del Reglamento (CE) $n .^{\circ} 2201 / 2003$ [...], debe interpretarse en el sentido de que no se opone, en principio, a que un Estado miembro atribuya a un tribunal especializado la competencia para examinar las cuestiones de restitución o de custodia del menor en el marco del procedimiento previsto por esas disposiciones incluso cuando un órgano jurisdiccional ya conozca por otra parte de un procedimiento sobre el fondo acerca de la responsabilidad parental en relación con el menor. 
Nota. 1. La Sentencia del TJUE de 9 de enero de 2015 dictada en el asunto C-498/14 tiene por objeto una cuestión prejudicial planteada por la Cour d'appel de Bruselas sobre la interpretación del art. 11, apdos. 7 y 8, del Reglamento 2201/2003 sobre materia matrimonial y responsabilidad parental, en el marco de la restitución de un menor entre Estados miembros de la UE. Concretamente, el tribunal conoció en esta ocasión de la sustracción de un menor de madre polaca y padre británico residente en Bélgica, que fue privado de relacionarse con su hijo cuando la madre viajó a Polonia con el menor y se negó a volver a Bruselas e incluso a comunicar los datos sobre la nueva residencia en Polonia.

2. El art. 11 del Reglamento 2201/2003 regula la sustracción de menores entre Estados miembros de la UE completando en ciertos aspectos la regulación proporcionada por el Convenio de La Haya de 1980 sobre los aspectos civiles de la sustracción internacional de menores, fundamentalmente mediante la incorporación de algunas garantías procedimentales que consolidan el sistema de La Haya [REIG FABADO, I., «Incidencia del Reglamento 2201/2003 en materia de sustracción internacional de menores: interacción con el Convenio de La Haya de 1980», en VVAA, Secuestro de menores en el ámbito familiar: un estudio interdisciplinar (coord. por P. LLORIA GARCÍA), Madrid, Iustel, 2008, pp. 220 y 228].

Uno de esos aspectos hace referencia a la posibilidad de que se dicte una resolución de no restitución del menor con base en el art. 13 de dicho instrumento, como sucede precisamente en este asunto. En tal caso, señala el art.11.7 del Reglamento $2201 / 2003$ que, salvo que alguna de las partes haya presentado ya una demanda ante los órganos jurisdiccionales del Estado miembro en el que el menor tenía su residencia habitual inmediatamente antes de su traslado o retención ilícitos, se deberá transmitir toda la información relativa a esta decisión al Estado miembro en el que el menor tenía su residencia habitual inmediatamente antes de su traslado, para notificar a las partes esta información e invitarles a presentar alegaciones con el fin de que el órgano judicial competente de conformidad con lo previsto por la legislación nacional (el considerado por la sentencia como «tribunal especializado» - juridiction spécialisée en la lengua de procedimiento-) examine la custodia del menor.

La aplicación de esta disposición dio lugar a plantear qué tribunal belga resultaba competente para conocer del asunto, dado que la custodia se había planteado ante el tribunal belga competente para conocer de la misma antes de que se atribuyera competencia al «tribunal especializado» conforme al Reglamento. Para entender mejor el planteamiento de la cuestión, interesa detenerse brevemente en los hechos que motivaron esta cuestión prejudicial.

3. Antoni nació en Polonia en diciembre de 2011, de la relación entre la Sra. Aleksandrowicz y el Sr. Bradbrooke. La madre y el menor se domiciliaron en Bruselas y el menor se reunía regularmente con su padre. Intentada una mediación con el fin de convenir el alojamiento del menor, no alcanzaron ningún acuerdo, y en octubre de 2013 la madre anunció al padre que se marchaba de vacaciones a Polonia con el hijo de ambos. Ese mismo mes el padre solicitó al Tribunal de la jeunesse de Bruselas que se pronunciara sobre el ejercicio de la patria potestad y el alojamiento del menor, a lo que añadió unos días más tarde solicitud de medidas provisionales para fijar el alojamiento secundario del menor en su domicilio. Modificó su pretensión cuando concluyó que la madre no tenía intención de volver a Bélgica con su hijo, solicitando entonces el ejercicio exclusivo de la patria potestad, el alojamiento principal del menor y que se prohibiera a la madre abandonar con éste el territorio belga. 
Si bien la madre impugnó la competencia internacional de los tribunales belgas solicitando la remisión del asunto a los tribunales polacos con base en el art. 15 del Reglamento 2201/2003 (por considerarlos mejor situados para conocer del asunto al residir el menor en Polonia y estar matriculado en una guardería), el juez belga se declaró competente, resolviendo el ejercicio conjunto de la patria potestad, además de atribuir a la madre el alojamiento principal del menor y conceder al padre provisionalmente el alojamiento secundario en fines de semana alternos, para lo que tendría que desplazarse a Polonia. El padre consideró que de este modo se validaba el traslado ilícito del menor, por lo que recurrió la decisión ante la Cour d'appel de Bruselas solicitando con carácter principal el ejercicio exclusivo de la patria potestad y el alojamiento principal del menor.

4. De forma paralela a la sustanciación de este proceso sobre el fondo del asunto, el padre presentó en noviembre de 2013 ante la Autoridad Central belga una solicitud para la restitución inmediata del menor a Bélgica según el procedimiento de restitución regulado por el Convenio de La Haya. Pero en febrero de 2014, el tribunal de distrito de Płońsk (Polonia), a pesar de haber declarado que el traslado del menor por parte de la madre había sido ilícito y que la residencia habitual del menor antes de ese traslado se encontraba en Bélgica, dictó una resolución de no restitución del menor basada en el art. 13, letra $b$ ), del Convenio [véase Paz Lamela, R. S., "Causas de no restitución del menor en los supuestos de sustracción internacional (Análisis a través de la jurisprudencia reciente)», $A F D U C, 2013$, núm. 17, pp. 675-685].

La Autoridad Central belga recibió copia de la resolución de no restitución por parte de la Autoridad Central polaca, y presentó ese expediente en el Tribunal de première instance francophone de Bruselas (el «tribunal especializado»), órgano competente para examinar la cuestión de la custodia del menor en virtud del Derecho belga vigente en ese momento conforme al art. 11, apdos. 6 y 7, del Reglamento 2201/2003 (posteriormente, una reforma legislativa trasladaría la competencia al Tribunal de la famille de Bruselas).

Ante tal situación, el Derecho belga preveía la suspensión de los procedimientos iniciados en materia de responsabilidad parental, o conexos, por lo que la Cour d'appel de Bruselas, ante la que el padre había recurrido la decisión del Tribunal de la jeunesse, aplazó el pronunciamiento sobre el fondo. Ahora bien, el padre ya había presentado esta demanda pendiente de recurso en el sentido del art. 11.7 del Reglamento, por lo que la Cour d'appel se pregunta si, dadas las exigencias de celeridad y de eficacia a las que debe responder el procedimiento previsto en el art. 11, apdos. 6 a 8, del Reglamento, el apdo. 7 de ese artículo se opone a que el Derecho de un Estado miembro atribuya a un tribunal especializado la competencia exclusiva para conocer de ese procedimiento (en este caso el Tribunal de première instance francophone y posteriormente el Tribunal de la famille de Bruselas) y establezca al mismo tiempo que todos los procedimientos relativos a la patria potestad ya iniciados deben suspenderse (en este caso el conocido por la Cour d'appel de Bruselas) desde el momento en que conozca del asunto dicho tribunal especializado

5. Por lo anterior resultaba oportuno plantear ante el Tribunal de Justicia la cuestión prejudicial con el fin de determinar el órgano judicial belga competente en virtud del Derecho de la Unión y, en especial, de decidir si correspondía a esa misma Cour d'appel, que conocía del procedimiento sobre el fondo, pronunciarse conforme al procedimiento previsto en el art. 11, apdos. 6 a 8, del Reglamento. La Cour d'appel de Bruselas suspendió el procedimiento y planteó ante el Tribunal de Justicia dos cuestiones: primera, si el art. 11, apdos. 7 y 8 , puede interpretarse en el sentido de que se 
opone a que un Estado miembro prime la especialización de los órganos judiciales en casos de sustracción de menores en relación con el procedimiento previsto por estas disposiciones, incluso cuando otro tribunal ya conozca de la responsabilidad parental respecto al menor, y segunda, si puede igualmente considerarse que se opone a que un Estado miembro prive de la competencia para resolver sobre la custodia del menor al tribunal que esté conociendo sobre la responsabilidad parental, a pesar de ser competente tanto a nivel internacional como nacional.

6. Al respecto considera el Tribunal de Justicia que ninguno de los apartados del art. 11 del Reglamento relevantes en este proceso (apdos. 6 a 8) designan el órgano judicial nacional competente para examinar las cuestiones de la restitución o de la custodia del menor en el marco del procedimiento previsto, sino que corresponde a los propios Estados miembros dada la remisión a su Derecho nacional, y ello incluso en el supuesto de que en la fecha de la notificación de la resolución de no restitución un órgano judicial ya conozca de un procedimiento sobre la responsabilidad parental. El Derecho nacional del Estado miembro de la residencia habitual anterior al traslado deberá determinar si cuando se ha presentado tal demanda con anterioridad a la resolución de no restitución, el órgano judicial que conoce de la misma pierde la competencia en favor de otros órganos judiciales de ese mismo Estado miembro.

Lo anterior deberá tener en cuenta, no obstante, que las normas de Derecho material y de procedimiento de los diferentes Estados miembros no deben menoscabar la eficacia del Reglamento, el cual, además, reconoce los derechos fundamentales y los principios consagrados en la Carta de Derechos Fundamentales de la Unión Europea, y en particular los derechos del menor enunciados en el art. 24, entre los cuales se encuentra el derecho a mantener de forma periódica relaciones personales y contactos directos con sus dos progenitores.

Carmen AzCÁRRaga Monzonís

Universidad de Valencia

http://dx.doi.org/10.17103/redi.67.2.2015.3b.07

\subsection{Reglamento $1346 / 2000$}

2015-27-Pr

REGLAMENTO (CE) NÚM. 1346/2000.-Aplicación.-Acción contra el administrador de la sociedad concursada.-Irrelevancia del domicilio del demandado.-Inaplicación del Convenio de Lugano.

Preceptos aplicados: art. 3 del Reglamento (CE) 1346/2000; art. 1.2.b) del Convenio de Lugano de 30 de octubre de 2007.

Sentencia del Tribunal de Justicia (Sala Sexta) de 4 de diciembre de 2014, asunto C-295/13, H. c. H.K. Ponente: M. Berger.

\section{F.: curia.europa.eu.}

24. Una interpretación del artículo 3, apartado 1, del Reglamento n. ${ }^{\circ}$ 1346/2000 en el sentido de que la acción basada en el artículo 64 de la GmbHG, ejercitada en el marco de un procedimiento de insolvencia, no se halla entre las acciones que se derivan directamente de un procedimiento de insolvencia y guardan inmediata relación con él, crearía pues una distinción artificial entre esta última acción y acciones comparables, 
como las acciones revocatorias controvertidas en los asuntos que dieron lugar a las sentencias Seagon (EU:C:2009:83) y F-Tex (EU:C:2012:215), por el mero hecho de que, teóricamente, la acción basada en el referido artículo 64 también podría ejercitarse aunque no existiese un procedimiento de insolvencia. Pues bien, esta interpretación, que no halla fundamento alguno en las disposiciones pertinentes del Reglamento $n .^{\circ}$ 1346/2000, no puede aceptarse.

25. No obstante, ha de precisarse que una acción basada en el artículo 64 de la GmbHG y ejercitada fuera de un procedimiento de insolvencia puede entrar dentro del ámbito de aplicación del Convenio de Lugano II o, en su caso, del Reglamento n. ${ }^{\circ}$ 44/2001. Sin embargo, éste no es el caso en el litigio principal.

26. En estas circunstancias, procede responder a las cuestiones prejudiciales primera y tercera que el artículo 3, apartado 1, del Reglamento $n .^{\circ}$ 1346/2000 debe interpretarse en el sentido de que los órganos jurisdiccionales del Estado miembro en cuyo territorio se haya incoado un procedimiento de insolvencia sobre el patrimonio de una sociedad son competentes, en virtud de dicha disposición, para conocer de una acción, como la controvertida en el litigio principal, ejercitada por el administrador concursal de la referida sociedad contra su administrador con el fin de obtener la devolución de los pagos realizados después de que se hubiera producido la insolvencia de la referida sociedad o se hubiese declarado la situación de endeudamiento de ésta. [...]

Sobre la segunda cuestión prejudicial [...]

31. En segundo término, procede recordar que en un asunto relativo, en particular, a la exclusión de "la quiebra, los convenios entre quebrado y acreedores y demás procedimientos análogos» del ámbito de aplicación del Reglamento n. $.^{\circ} 44 / 2001$, establecida en el artículo 1, apartado 2, letra b), de dicho Reglamento en términos prácticamente idénticos a los del artículo 1, apartado 2, letra b), del Convenio de Lugano II, el Tribunal de Justicia declaró que, esta exclusión, por un lado, y el ámbito de aplicación del Reglamento $n .^{\circ} 1346 / 2000$, por otro lado, deben interpretarse de tal manera que se evite todo solapamiento entre las normas jurídicas que ambos textos establecen. Por consiguiente, en la medida en que una acción entra dentro del ámbito de aplicación del artículo 3, apartado 1, del Reglamento $n .^{\circ} 1346 / 2000$, no está comprendida en el ámbito de aplicación del Reglamento n. ${ }^{\circ}$ 44/2001 (véase, en este sentido, la sentencia Nickel \& Goeldner Spedition, EU:C:2014:2145, apartado 21 y la jurisprudencia citada).

32. Pues bien, habida cuenta, en particular, del tenor prácticamente idéntico de las disposiciones de que se trata, las consideraciones que se recuerdan en el anterior apartado pueden extrapolarse a la interpretación artículo 1, apartado 2, letra b), del Convenio de Lugano II. En consecuencia, dado que la acción del litigio principal entra dentro del ámbito de aplicación del artículo 3, apartado 1, del Reglamento n..$^{\circ}$ 1346/2000, queda excluida del ámbito de aplicación del referido Convenio. En tales circunstancias, el hecho de que la Confederación Suiza sea parte del Convenio de Lugano II carece de pertinencia para la solución del litigio principal, puesto que dicho Convenio no resulta aplicable a este litigio.

Nota. 1. Tras abrirse un procedimiento de insolvencia en Alemania, el síndico entabla aquí una acción contra el administrador de la sociedad concursada, que tiene domicilio en Suiza, por haber ordenado la transferencia de fondos de la concursada a una de sus filiales, cuando aquella ya estaba en situación de insolvencia o endeudamiento. Se trata de una acción regulada en el art. 64 de la Ley alemana de sociedades de responsabilidad limitada (GmbHG) que, a mi juicio, no puede considerarse concursal, ya que no presenta una vinculación especial ni sustantiva ni procesal con el concurso, de acuerdo con los requisitos exigidos por la jurisprudencia del Tribunal 
(STJUE de 12 de febrero de 2009, C-339/07, Seagon, apdo. 21; STJUE de 4 de septiembre de 2014, Nickel c. Goeldner Spedition, C-157/13, apdo. 26). Esta acción no se fundamenta en la legislación de insolvencia y, de hecho, puede ser ejercitada sin la apertura de un procedimiento previo de insolvencia (apdo. 15 de la sentencia). En consecuencia, el Reglamento (CE) núm. 1346/2000, sobre procedimientos de insolvencia [texto refundido Reglamento (UE) 2015/848 para procedimientos abiertos a partir del 26 de junio de 2017] no debería reclamar su aplicación, al contrario que las normas generales de Derecho procesal internacional y, en particular, el Convenio de Lugano de 30 de octubre de 2007, por tener el demandado su domicilio en Suiza [art. 64.2.a)].

Lejos de este planteamiento, y no muy en sintonía con su jurisprudencia anterior, el Tribunal realiza una criticable interpretación según la cual esta acción de responsabilidad tiene carácter concursal. Por tanto, los tribunales del Estado donde se abre el concurso, Alemania, tienen competencia para conocer por razón de la materia ex art. 3 del Reglamento europeo de insolvencia (apdo. 33 de la sentencia). Ello tiene, además, una consecuencia añadida: desde el momento en el que el Tribunal califica la acción como concursal, ésta queda excluida ratione materiae del Convenio de Lugano de 30 de octubre de 2007 [art. 1.2.b)], aunque, ratione loci, el demandado esté domiciliado en Suiza. No en vano, la materia incluida en el Reglamento europeo de insolvencia queda automáticamente excluida de los instrumentos generales (STJUE de 4 de septiembre de 2014, C-157/13 Nickel c. Goeldner Spedition, apdo. 21; y apdo. 32 de la presente sentencia). Para llegar a esta discutible calificación concursal, el Tribunal recurre a dos parámetros: el análisis individualizado de la acción y su comparación con otras acciones equivalentes. Ninguno de ellos resulta convincente.

2. En relación con el análisis individualizado de la acción de la Ley alemana de sociedades de responsabilidad limitada, el Tribunal asume los argumentos de la Comisión sobre que la finalidad de la acción «forma parte del Derecho concursal» y del interés de todos los acreedores de la sociedad, además de razones de agilidad y eficacia procesal (apdo. 16). Se obvia que hay acciones no concursales que interesan a la masa y que la propia Comisión reconoce que, incluso recurriendo a la finalidad de la acción, no se cumplen todos los requisitos jurisprudenciales para la calificación de la acción como concursal (apdo. 16). Asimismo, el Tribunal argumenta que la acción se ejercita "con ocasión de un procedimiento de insolvencia» (apdo. 19), elevando a categoría general una circunstancia coyuntural: la coincidencia, que puede darse o no, entre la interposición de la acción y la apertura de un concurso. Por último, el Tribunal "cuadra el círculo» señalando que se trata de una norma especial para la «insolvencia material» (apdo. 22). Olvida, siguiendo con su terminología, que el Reglamento europeo de insolvencia no se ocupa de esta «insolvencia material», sino de la apertura «formal» de un concurso. Olvida, también, que no basta con que se trate de una norma «especial» respecto del Derecho civil general, sino que sea una norma especial "propia de los procedimientos de insolvencia» (cfr. apdo. 21 de la presente Sentencia que no es tenido en cuenta en la ratio decidendi; y STJUE de 4 de septiembre de 2014, Nickel c. Goeldner Spedition, cit., apdo. 27). El hecho de que la acción se ubique en la Ley de sociedades de responsabilidad limitada, y no en la Ley de insolvencia, parece bastante revelador.

3. Si el análisis individualizado de esta acción no convence, tampoco lo hace el segundo parámetro de interpretación de la sentencia: la comparación con otras acciones «concursales» y la intención del Tribunal de huir de lo que denomina una «distinción artificial» (apdo. 24). De entrada, no es fácil ver por qué es artificial distinguir entre acciones que tienen un presupuesto procesal distinto, en unas, la apertura de 
concurso, en otras no. Máxime cuando la distinción está en las propias legislaciones nacionales a las que remite la jurisprudencia del Tribunal de Justicia para una adecuada calificación. Además, el nuevo texto refundido, el Reglamento (UE) 2015/848 - cuya tramitación ya estaba muy avanzada en el momento de dictar la sentencia-, incluye un nuevo art. 6 que asume esta distinción considerada artificial por el Tribunal. Así ocurre cuando regula la conexidad entre las acciones en materia «concursal» y las acciones «en materia civil y mercantil» ejercitadas durante el concurso que no por ello pasan a calificarse como concursales. Igualmente, la comparación de la acción valorada en la sentencia con las acciones revocatorias tratadas en los asuntos Seagon (STJUE de 12 de febrero de 2009, cit.) y F-Tex (STJUE de 19 de abril de 2012, C-213/10) resulta poco apropiada. No existe una equivalencia funcional entre ellas: la acción revocatoria busca, a través de normas especiales de Derecho concursal, invalidar el acto hecho en fraude de acreedores siendo el demandado normalmente el beneficiario de tal acto; en cambio, la acción aquí enjuiciada se dirige contra el administrador de la propia sociedad concursada, en clave de responsabilidad patrimonial, sin atacar directamente el acto hecho en fraude ni contar con una regulación especial de Derecho concursal. Es más, si se quieren buscar acciones comparables, el Tribunal debería haberse referido a la acción de responsabilidad del administrador por no solicitar la liquidación de la sociedad, que fue calificada como no concursal, aún cuando se solapara con un procedimiento de insolvencia, en el Asunto ÖFAB (STJUE de 18 de julio de 2013, As. C-147/12, esp. apdo. 25). Las contradicciones entre esta Sentencia de la Sala 5. a , ni siquiera citada, y la presente resolución de la Sala 6. ${ }^{a}$ son llamativas.

4. En resumen, discrepo de la argumentación e interpretación de la sentencia en lo que atañe a la calificación de esta acción como «concursal», dadas su fundamentación en la legislación societaria y su desvinculación del procedimiento concursal. En cualquier caso, de asumir esta calificación concursal, sí parece claro que la aplicación del Reglamento europeo de insolvencia no depende del domicilio del demandado y, por tanto, es irrelevante que éste no se encuentre en un Estado miembro de la UE. Su ámbito espacial se define en función del concursado, que sí ha de tener su centro de intereses principales en la UE, y no del demandado, en lo que es jurisprudencia consolidada (STJUE de 16 de enero de 2014, C-328/12, Schmid) y menos vacilante que la relativa al ámbito material.

\author{
Ángel EsPiniella MENÉNDEZ \\ Universidad de Oviedo \\ http://dx.doi.org/10.17103/redi.67.2.2015.3b.08
}

2015-28-Pr

ACCIÓN REVOCATORIA CONCURSAL.-Ley aplicable.-Impugnación pauliana concursal de pago realizado tras apertura de concurso en otro Estado miembro como consecuencia de embargo practicado con anterioridad.-Efectos del concurso y ley aplicable a las garantías reales.

Preceptos aplicados: arts. 4, 5, 13 y 20 del Reglamento 1346/2000, de 20 de mayo, sobre procedimientos de insolvencia; art. 12.1 del Reglamento 593/2008, de 17 de junio, sobre la ley aplicable a las obligaciones contractuales.

Sentencia del Tribunal de Justicia, de 16 de abril de 2015, asunto C-557/13, Hermann Lutz y Elke Bäuerle, en calidad de síndico de ECZ Autohandel GmbH. Ponente: M. Berger.

\title{
F.: curia.europa.eu.
}


1) El artículo 13 del Reglamento (CE) n. ${ }^{\circ} 1346 / 2000$ del Consejo, de 29 de mayo de 2000, sobre procedimientos de insolvencia, debe interpretarse en el sentido de que es aplicable a una situación en la que el abono, impugnado por un síndico, de un importe de dinero que había sido embargado antes de la apertura del procedimiento de insolvencia se realizó con posterioridad a la apertura de dicho procedimiento.

2) El artículo 13 del Reglamento $n .^{\circ} 1346 / 2000$ debe interpretarse en el sentido de que la excepción que establece incluye también los plazos de prescripción, anulabilidady caducidad previstos en la ley a la que esté sujeto el acto impugnado por el síndico.

3) Los requisitos de forma para el ejercicio de una acción revocatoria se rigen, a efectos de la aplicación del artículo 13 del Reglamento $n .^{\circ} 1346 / 2000$, por la ley a la que esté sujeto el acto impugnado por el síndico.

Nota. 1. Las tres cuestiones prejudiciales que el Tribunal de Justicia (en adelante, TJUE) decide en esta sentencia de 16 de abril de 2015 versan sobre la interpretación del art. 13 del Reglamento (CE) 1346/2000, de 29 de mayo, sobre procedimientos de insolvencia (en adelante RI), precepto que excepciona la aplicación de la lex fori concursus impuesta por el art. 4 del RI, «con el fin de proteger las expectativas legítimas y la seguridad de las operaciones en Estados miembros distintos a aquel en el que se inicia el procedimiento» (Cdo. 24 del RI). A estos efectos, si las normas relativas a la nulidad, anulación o inoponibilidad de actos perjudiciales al conjunto de acreedores de la lex fori concursus permitieran la revocación de un acto realizado por el deudor beneficiando a un tercero, este último puede alegar que dicho acto se rige por la ley de un Estado miembro distinto del de la apertura del concurso y esta ley «no permite en ningún caso que se impugne dicho acto».

El meollo del asunto aquí discutido concierne a qué tipo de normas se refiere el art. 13: ECZ era una sociedad alemana que operaba en Austria a través de una filial que vendió un vehículo al Sr. Lutz, a quien nunca le fue entregado. Solicitada la devolución de lo pagado en Austria, el órgano jurisdiccional emite un requerimiento de pago el 17 de marzo de 2008, al que poco después sigue el embargo de tres cuentas bancarias abiertas en una entidad de crédito austríaca. Un mes más tarde al requerimiento la citada filial solicita la apertura de procedimiento de insolvencia en Alemania y cuando transcurrido un año la entidad de crédito paga al Sr. Lutz, la administración concursal decide interponer una acción revocatoria concursal, también conocida como acción de reintegración de la masa o acción pauliana concursal, frente a dicho pago. Clave en las preguntas al TJUE es, de una parte, el que el pago se realice después de la apertura del procedimiento de insolvencia, de otra parte, que la ley rectora del acto impugnado establezca un plazo para su impugnación distinto del prescrito por la ley concursal aplicable. El apdo. 3 de esta nota se refiere a estas cuestiones en tanto que el 2 lo hace al acto impugnado en sí mismo considerado, la ejecución forzosa de la condena al deudor, puesto que el TJUE se detiene en su caracterización como garantía real. El apdo. 4 cierra la nota con algunas observaciones sobre las consecuencias de esta normativa que, por otra parte, no ha sido modificada en el Reglamento (UE) 2015/848, de 20 de mayo de 2015, por el que se modifica el RI (en adelante, RIbis). En consecuencia, la doctrina aquí sentada es plenamente transferible a la interpretación de los arts. 7, 8 y 16 del RIbis.

2. Antes de entrar a examinar las cuestiones prejudiciales, el TJUE recuerda que las acciones revocatorias concursales también se pueden utilizar frente a garantías reales (art. 5.4 del RI). La precisión es importante porque el art. 5 del RI establece la no afectación de las mismas por los efectos del concurso abierto en un Estado miembro distinto de dónde se localizan los bienes objeto de garantía; ergo el acreedor 
garantizado puede actuar como si no existiera el concurso. El privilegio no impide, sin embargo, que se impugne la constitución, ampliación, etcétera, de la garantía real por ser perjudicial al conjunto de los acreedores, si bien esta impugnación puede ser paralizada por el juego del art. 13: aunque el art. 5.4 no se refiera a él expresamente hay que entender que si es aplicable la regla, también lo es la excepción. La digresión del TJUE en esta decisión sobre la naturaleza del embargo como garantía real estaría así justificada, ya que se trata de afirmar que el acreedor garantizado también puede vetar la reintegración de la masa ordenada por la ley concursal (apdos. 30, 31 y 42 de la sentencia). Y para ello necesita entrar en la calificación del embargo de cuentas bancarias como garantía real. Qué se entienda por derechos reales de terceros es una cuestión que queda a la correspondiente ley nacional (Cdo. 25 del RI), esto es, a la lex rei sitae; aunque el propio art. 5.2 del RI da algunas pistas sobre qué ha de entenderse por tal como la de que presente «carácter exclusivo frente a los demás acreedores de la sociedad deudora» (apdo. 28). Corresponde, en consecuencia, a la ley austríaca en tanto que rectora del procedimiento de ejecución en el marco del cual se ordena el embargo decidir si estamos ante una garantía real o no, así como el momento en que se entiende efectivamente constituido el derecho real, puesto que el art. 5.1 del RI se refiere a garantías reales que ya hubieran nacido al tiempo de la apertura del concurso (apdo. 37). En cambio, la decisión sobre la localización del bien, que es clave en la aplicación de la consecuencia jurídica del art. 5 del RI (y también en la determinación de la ley aplicable), depende de lo dispuesto en el art. 2 del RI.

3. El pago al Sr. Lutz se realiza después de la apertura del concurso por lo que cabe la duda de si este tipo de actos está cubierto por las normas a las que se refiere el art. 4.2.m) y, en particular, el art. 13 del RI que, como excepción que es a la ley concursal, ha de interpretarse de forma estricta (apdos. 34 a 36): la protección de las expectativas de terceros y la seguridad de las transacciones se sostiene, tras la apertura del concurso, en el régimen de publicidad que imponga la correspondiente ley concursal, de ahí que no haya espacio para una regla como la prescrita en el art. 13 del RI. Ahora bien, en este caso concreto lo relevante es que el derecho de embargo se habría constituido antes de la apertura del concurso según el derecho austríaco, de manera que si el acreedor garantizado lo puede hacer valer con independencia del concurso, la administración concursal puede impugnarlo en tanto que perjudicial al conjunto de los acreedores (apdo. 41).

La segunda cuestión prejudicial pregunta si el ámbito del art. 13 del RI también comprende los plazos de prescripción, anulabilidad y caducidad previstos en la ley rectora del acto impugnado. El TJUE precisa que el ámbito de aplicación de la lex causae depende de lo indicado por el art. 12 del Reglamento (CE) 593/2008, sobre ley aplicable a las obligaciones contractuales, pero dicha disposición no es aplicable a las acciones revocatorias concursales (apdo. 46). La afirmación es sorprendente puesto que estas acciones no sólo impugnan obligaciones contractuales de modo que el TJUE hubiera debido descartar otros preceptos como el art. 15 del Reglamento (CE) 864/2008, sobre ley aplicable a las obligaciones extracontractuales. La explicación de esta referencia, siquiera incompleta, se encuentra en que el Sr. Lutz invoca el transcurso del plazo de caducidad contenido en la ley concursal austríaca para interponer la acción revocatoria concursal, que comienza a correr a partir de la apertura del concurso; la ley concursal alemana, aquí la lex fori concursus, prescribe que la impugnación se puede plantear en los tres años siguientes. A fin de salvar el éxito de la acción, se arguye que el art. 13 del RI no se refiere a normas procesales, sino sustantivas. Más, ubi lex non distinguit... lo que el TJUE aplica a rajatabla (apdos. 47 y 48). 
Todavía persiguiendo evitar la aplicación del art. 13 del RI se cuestiona si los requisitos de forma de la acción pauliana concursal se rigen por la lex causae (y, por tanto, el derecho austríaco y su plazo de caducidad) o por la lex fori concursus. Y esta cuestión prejudicial recibe prácticamente la misma respuesta que la anterior (apdo. 53), esto es, que la distinción no procede sino se impone la consecuencia jurídica del art. 13, el que, en ningún caso, la ley rectora del acto permita su impugnación, sea porque sus reglas sustantivas no contemplan causa alguna, sea porque sus reglas procesales impiden que prospere la acción correspondiente.

4. La ortodoxia del RI se ha impuesto en esta sentencia del TJUE que no trae consigo novedad alguna y sí subraya las consecuencias a las que aboca la exagerada protección de las expectativas de terceros y la seguridad de las transacciones. El art. 13 del RI implica que se acumulan dos leyes a efectos de decidir si prosperan las acciones paulianas concursales de modo que se dificulta enormemente su éxito, cuando no se imposibilita como ocurre en este caso, lo que claramente desincentiva la interposición de este tipo de acciones que cuestan dinero y son tan difíciles de fundamentar. A pesar de ello, el RIbis no cambia las normas examinadas asumiendo, como concluye el informe que acompaña su propuesta, que la ausencia de jurisprudencia es indicativa de que no existe controversia y la regla prescrita por el art. 13 del RI es valiosa ya que, efectivamente, protege las expectativas de terceros a través de la aplicación de la lex causae. Si bien esto último es cierto, es claro también que con esta regla se renuncia en gran medida a la consecución de los objetivos concursales, entre ellos el acrecimiento de la masa concursal y el respeto del orden de distribución de activos entre acreedores, también antes de la apertura del concurso. Al respecto, cabe traer a colación la sentencia del TJUE de 12 de febrero de 2009 (C-339/07, Seagon v. Deko Marty Belgium, REDI, 2009-3-Pr, con nota de EsPiniella Menéndez, A.), donde se afirma la calificación concursal de las acciones aquí discutidas. Partiendo de esta calificación, cabe destacar que las expectativas de los terceros beneficiados por el acto impugnado también se ven protegidas por la aplicación de la lex fori concursus, claramente cuando ésta es la ley del país donde se halla el centro de los intereses principales del deudor, con matices cuando es la ley del país en el que el deudor tiene un establecimiento (CARballo PiñeIro, L., Acciones de reintegración de la masa y derecho concursal internacional, Santiago de Compostela, Universidad de Santiago de Compostela, 2004, pp. 196-200); en ninguno de estos supuestos el tercero beneficiado por el acto impugnado puede alegar que dichas leyes no le eran conocidas y que no pudo examinar su contenido antes de entrar en tratos con el deudor. Por el contrario, la supresión del art. 13 del RIbis ayudaría a proteger el conjunto de los acreedores y los objetivos del concurso.

Esta supresión se hace más evidente a la luz de las recientes evoluciones del Derecho concursal que se ponen de manifiesto en la estrategia de la Unión Europea dirigida a implantar una nueva cultura que promueva el fresh start. En esta dirección el RIbis da entrada a procedimientos pre-concursales dirigidos a celebrar acuerdos que permitan refinanciar o reestructurar la empresa y, por tanto, salvarla. La clave de su éxito está en que, en ciertas circunstancias, también vinculan a acreedores garantizados. Pues bien, los arts. 5 y 13 del RI, y 7 y 16 del RIbis, aseguran una posición de fuerza a los titulares de garantías reales sobre bienes localizados en Estados miembros distintos del de la apertura del concurso, no sólo porque no les afecta el concurso, sino también por las dificultades en impugnar dichas garantías cuando perjudican a acreedores, dejando en sus manos la viabilidad de la empresa en ciertos casos (CARBALlo PIÑEIRO, L., «Towards the Reform of the European Insolvency Regulation: Codification rather than Modification», NIPR, 2014, pp. 207-215, pp. 211-212). En definitiva, esta 
sentencia del TJUE aplica una lógica que cabe cuestionar sea la propia del concurso y que tiene el potencial de erosionar aquello que persigue proteger, el acceso al crédito del deudor en dificultades.

Laura CARBALlo PiÑEIRO

Universidad de Santiago de Compostela http://dx.doi.org/10.17103/redi.67.2.2015.3b.09

\subsection{Proceso monitorio europeo}

2015-29-Pr

REQUERIMIENTO EUROPEO DE PAGO.-Falta de notificación válida.-Revisión.--Respeto del derecho de defensa.-Remisión a los ordenamientos nacionales.

Preceptos aplicados: arts. 13 a 20 y art. 26 del Reglamento (CE) núm. 1896/2006.

Sentencia del Tribunal de Justicia de 4 de septiembre de 2014, asuntos acumulados C-119/2013 y C-120/2013. Eco cosmetics GmbH \& Co. KG y Virginie Laetitia Barbara Dupuy (C-119/13); Raiffeisenbank St. Georgen reg. Gen. mbH y Tetyana Bonchyk (C-120/13). Ponente: C. Toader.

\section{F.: curia.europa.eu.}

El Reglamento (CE) n. ${ }^{\circ}$ 1896/2006 del Parlamento Europeo y del Consejo, de 12 de diciembre de 2006, por el que se establece un proceso monitorio europeo, debe interpretarse en el sentido de que los procedimientos previstos en los artículos 16 a 20 de dicho Reglamento no son aplicables cuando resulta que un requerimiento europeo de pago no ha sido notificado de una forma que cumpla los requisitos mínimos establecidos en los artículos 13 a 15 de ese Reglamento.

Cuando sólo después de la declaración de fuerza ejecutiva de un requerimiento europeo de pago se ponga de manifiesto tal irregularidad, el demandado debe tener la posibilidad de denunciar esa irregularidad, la cual, si se demuestra debidamente, debe entrañar la invalidez de dicha declaración de fuerza ejecutiva.

Nota. 1. El art. 20 del Reglamento (CE) núm. 1896/2006 por el que se establece un proceso monitorio europeo ha sido siempre objeto de crítica en la doctrina. La práctica da la razón a los autores: el reglamento no ha suscitado una decena de cuestiones prejudiciales, y ya la mitad se refieren a la interpretación de dicha norma -el Asunto C-324/12; el que ahora comentamos, que agrupa dos; y el pendiente Asunto C-245/14-.

2. En la sentencia de 4 de septiembre de 2014, el TJ responde a los asuntos acumulados C-119/13 y C-120/13. Originalmente las cuestiones eran tres: una quedó sin objeto. El juez nacional alemán (Amtsgericht Wedding) expresa al TJ sus dudas sobre el derecho del deudor de pedir la revisión judicial del requerimiento europeo de pago, cuando éste no le ha sido notificado válidamente o en absoluto, de forma que cuando el deudor lo conoce ya ha sido declarado ejecutivo.

En el Asunto C-119/13, Eco cosmetics, la sociedad alemana Eco cosmetics presentó una petición de requerimiento europeo de pago ante el Amtsgericht Wedding contra la Sra. Dupuy, residente en Francia. Como domicilio la demandada indicó una 
dirección en Francia. El 22 de marzo de 2010, el Amtsgericht expidió el requerimiento europeo de pago, que se notificó mediante correo certificado enviado a la dirección indicada con acuse de recibo; la fecha de la notificación fue el 31 de marzo de 2010. Al no haber oposición por parte de la Sra. Dupuy, en mayo de 2010 el Amtsgericht dictó la declaración de ejecutividad conforme al art. 18.1 del Reglamento núm. 1896/2006. Mediante escrito de 28 de julio de 2010 la demandada formuló oposición al requerimiento europeo de pago; dos días más tarde el Amtsgericht Wedding indicó a la Sra. Dupuy que la oposición se había presentado fuera de plazo y que, en todo caso, podía presentar una solicitud de revisión del requerimiento con arreglo al art. 20 del Reglamento núm. 1896/2006. La Sra. Dupuy solicitó la revisión por escrito de 7 de octubre de 2010: el requerimiento europeo de pago no le fue notificado en ningún momento, dado que no residía en la vivienda situada en la dirección indicada por Eco cosmetics desde octubre de 2009; no tuvo noticia del requerimiento hasta que recibió una carta de su banco de 23 de julio de 2010.

En el Asunto C-120/3013, Raiffeisenbank St. Georgen, un Banco austríaco solicitó un requerimiento europeo de pago contra la Sra. Bonchyk, con domicilio en Alemania. El requerimiento se expidió el 2 de septiembre de 2010. Tras dos intentos fallidos de notificación la orden fue notificada a otra dirección proporcionada por el demandante el 1 de febrero de 2011. Ante la falta de reacción del deudor, el 10 de marzo de 2011 el tribunal declaró la orden ejecutiva. El 1 de junio de 2011, la Sra. Bonchyk formuló oposición al mencionado requerimiento, alegando también que sólo había tenido conocimiento del requerimiento de pago de forma casual, y que no vivía en la dirección en la que se efectuó la notificación desde el año 2009. El Amtsgericht Wedding declaró mediante escrito de 17 de junio de 2011 que la oposición formulada por la Sra. Bonchyk se había presentado fuera de plazo y que, en todo caso, podía presentarse una solicitud de revisión conforme al art. 20 del Reglamento núm. 1896/2006. La Sra. Bonchyk solicitó la revisión del requerimiento europeo de pago mediante escrito de 24 de junio de 2011.

3. Del recurso de revisión del art. 20 se ha dicho que quien lo ha concebido «ne le prend pas vraiment au sérieux» (LóPEZ DE TEJADA, M. y D’Avout, L., "Les non-dits de la procédure européenne d'injonction de payer. Règlement (CE) núm. 1896/2006, du 12 décembre 2006», Rev.cr.dr.int.pr., 2007, pp. 717 y ss., apdo. II B.2). El motivo, la ausencia de previsión legal de aspectos tan relevantes como el plazo para recurrir; un formulario al efecto (en un instrumento donde los formularios son clave); o el procedimiento para canalizar el recurso. Los asuntos C-119/13 y C-120/13 nacen también de un aspecto que el precepto no contempla: un punto que en realidad carece de cualquier regulación en el reglamento, y que el AG califica de «laguna» (Conclusiones, de 9 de abril de 1024, núm. 27). La pregunta del juez nacional de referencia se plantea en términos de aplicación analógica del art. 20: el supuesto que recoge el precepto es el de una notificación regular; en el que subyace a la cuestión prejudicial lo que se plantea es la ausencia de toda notificación, o una notificación irregular.

La respuesta del TJ, como la del AG, es negativa. No hay una coincidencia total en los argumentos, sin embargo; no la hay tampoco en el alcance de sus pronunciamientos respectivos. En cuanto al primer aspecto, el TJ rechaza la analogía apoyándose sin más en la letra del propio art. 20, que restringe la revisión a casos excepcionales, sumada a la letra del art. 26, que remite a los ordenamientos de los Estados miembros para todas las cuestiones no expresamente reguladas en el instrumento europeo. El razonamiento es pobre: se echa en falta un análisis de la similitud entre las situaciones en causa, y de la idoneidad de la revisión, sus condiciones y sus efectos para el caso de 
falta de notificación o notificación irregular. A este respecto son algo más elaboradas las conclusiones del AG (núm. 45), aunque tampoco lo bastante explícitas, ni claras.

A propósito del segundo aspecto, esto es, sobre el diferente alcance de las respuestas del AG y el TJ, ambos coinciden en que en ausencia de regulación en el Reglamento corresponde intervenir al legislador nacional proporcionando un recurso al demandado. Ahora bien, mientras que para el AG dicho recurso tendrá por objeto la declaración de nulidad del requerimiento de pago (punto 2 de su propuesta), en el fallo del TJ su objeto es invalidar la declaración de fuerza ejecutiva (párr. 2 del fallo). Tal solución, tomada aisladamente, es sorprendente: literalmente no se va a ver afectada la fuerza ejecutiva que el requerimiento adquiere ipso iure pasado el plazo de oposición (art. 16), sino sólo la declaración que ha lugar terminado dicho plazo (art. 18). Una lectura integrada del fallo indica que en realidad en opinión del TJ un supuesto como el controvertido está al margen del sistema: la notificación del requerimiento en una forma que no cumpla los requisitos de los arts. 13 a 15 del Reglamento impide que entren en juego los mecanismos consecutivos — posibilidad de oposición y consecuencias de ésta, o de su falta. Debe entenderse, en consecuencia, que el recurso dirigido a invalidar la declaración de fuerza ejecutiva pretende en realidad la nulidad de todas las actuaciones que suceden a la expedición del requerimiento —no, en cambio, de la expedición misma, como sí ocurriría de haberse optado por la solución del AG.

4. La doctrina se ha manifestado crítica con el TJ (HESS, B. y RAFFELSIEPER, K., «Schuldnerschutz bei fehlender Zustellung eines EU-Mahnbescheids: Regelungslücken der EuMahnVO», IPRax, 2015, fasc. 5, pp. 1-4, apdo. III). La «devolución» que opera a los ordenamientos nacionales se considera fuente de inseguridad jurídica; se añade que rompe con la armonización del procedimiento europeo mismo, y convierte en letra muerta lo previsto en el art. 24 del Reglamento, conforme al cual no se exigirá representación al demandante para solicitar el requerimiento, ni al demandado para oponerse.

Si el fondo de la crítica se comparte — de lo que se trata, al fin y al cabo, es de ofrecer un procedimiento simple y fácil de manejar para las partes-, no sucede lo mismo con sus argumentos. El art. 20 provoca él mismo falta de uniformidad: cada Estado miembro decide cuál (o cuáles, si se opta por varios en función del apartado

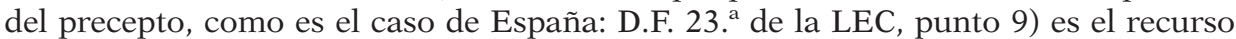
que canaliza la revisión. Así las cosas, la diferencia real respecto de la propuesta del TJ radica en la publicidad añadida que recibe el procedimiento «nacional» de revisión, por virtud de lo previsto en el art. 29.2.

Tampoco es exacta la crítica relativa al art. 24, puesto que el mismo no comprende la revisión entre los procedimientos para los cuales la representación no se exige.

5. Lo anterior no elimina ni resta trascendencia a un hecho: la dificultad del Amstgericht Wedding para dar satisfacción al fallo del TJ, a la luz de los medios disponibles en el ordenamiento alemán (HEss, B. y RAFFELSIEPER, K., op. cit., apdo. IV); ahora bien, es discutible que esto sea imputable al órgano de la UE. Sobre la situación en España, ya los comentarios al Reglamento (CE) núm. 805/2004, sobre el título ejecutivo europeo para créditos no impugnados, art. 19 (idéntico al art. 20 en sus dos primeros motivos, aunque su función es otra: véase, crítica, García CaNo, S., Estudio sobre el proceso monitorio europeo, Cizur Menor (Navarra), Thomson - Aranzadi, 2008, núm. 174), presumían o directamente afirmaban la remisión al ordenamiento nacional para el caso de la notificación irregular, cuya sanción habría de ser la nulidad de actuaciones (GAScón Inchausti, F., El título ejecutivo europeo para créditos 
no impugnados, Cizur Menor (Navarra), Aranzadi, 2005, núm. 160-161; GARCIMARTín AlfÉREZ, F. J., El título ejecutivo europeo, Cizur Menor (Navarra), Civitas, 2006, núm. 110, nota 45). Actualmente la D.F. 23. a de la LEC establece que la revisión de un requerimiento europeo de pago por las causas previstas en el art. 20.1 del Reglamento se tramitará y resolverá conforme a lo previsto para la rescisión de sentencias firmes a instancia del litigante rebelde en los arts. 501 y concordantes de la Ley; mientras que la revisión prevista en el art. 20.2 se tramitará por medio del incidente de nulidad de actos judiciales conforme al art. 241 de la LOPJ. Sobre este último punto cabe pensar que excluida por el TJ la aplicación analógica del art. 20 al caso de la notificación irregular o inexistente, se impone identificar otro recurso: no vale, por tanto, la propuesta doctrinal antes descrita.

Marta REQueJo IsIDRo

Max Planck Institute Luxembourg for International, European and Regulatory Procedural Law http://dx.doi.org/10.17103/redi.67.2.2015.3b.10

\section{PRÁCTICA ESPAÑOLA: DERECHO JUDICIAL INTERNACIONAL}

\subsection{Aplicación judicial del Derecho extranjero}

2015-30-Pr

DERECHO EXTRANJERO.-Aplicación en España.-Cesión de créditos.-Demanda del cesionario contra los deudores.-Ley aplicable: ley holandesa.Prueba del Derecho extranjero.-Inexistencia de obligación del tribunal de investigarlo de oficio.-Consecuenicas de la falta de prueba del Derecho extranjero: aplicación del Derecho español.

Preceptos aplicados: arts. 3, 4 y 8 del Convenio de Roma de 1980 sobre ley aplicable a las obligaciones contractuales; arts. 9, 10.5, 12.6 del CC; art. 281 de la LEC.

Sentencia del Tribunal Supremo (Sala de lo Civil, Sección 1. a) núm. 198/2015 de 17 abril de 2015. Ponente: Rafael Saraza Jimena.

\section{F.: Aranzadi Westlaw, RJ 2015/1350.}

[...] La Audiencia Provincial entendió que los demandados no habian alegado la falta de competencia internacional, por lo que los tribunales españoles eran competentes por existir una sumisión tácita de los demandados.

Consideró que el Derecho aplicable era el holandés, por determinarlo así el art. 10.5 del Código Civil y el art. 4 del Convenio de Roma de 19 de junio de 1980 , aplicable a las obligaciones contractuales. En el caso de la cesión del crédito, porque las partes se habian sometido expresamente al Derecho holandés. En el caso de los préstamos, porque se habian celebrado en Holanda [...].

En cuanto al carácter solidario de la deuda, al no haberse probado el Derecho holandés sobre este particular, debia aplicarse el Derecho español como «lex fori» [ley del lugar del juicio]. La Audiencia Provincial consideró aplicable la figura de la solidaridad tácita, por existir entre los obligados una comunidad jurídica de objetivos, manifestándose una interna conexión entre todos ellos, apareciendo de modo evidente la intención de los contratantes de obligarse «in solidum» [...]. 
La Audiencia consideró que los demandados no se oponían al cálculo de los intereses reclamados, sino a que los mismos fueran debidos porque consideraban que no era aplicable la legislación holandesa, al considerar aplicable la española, con arreglo a la cual, los demandados alegaban que los intereses eran usurarios. Pero rechazó esta alegación porque consideró aplicable la normativa holandesa y los demandados no habian probado que en Holanda existiera una norma equivalente a la Ley de Represión de la Usura de 23 de julio de 1908 existente en España [...].

Plantea también la recurrente que se han infringido las reglas de carga de la prueba en relación al Derecho holandés.

Para abordar esta cuestión, que vuelve a ser planteada en sucesivos motivos, debe precisarse.

Cuál es el régimen de prueba y de carga de la prueba del Derecho extranjero [...]. Esta doctrina puede resumirse en los siguientes puntos:

i) El tribunal español debe aplicar de oficio las normas de conflicto del Derecho español (art. 12.6 del Código Civil), que pueden ser de origen interno, comunitario o convencional internacional. La calificación para determinar la norma de conflicto aplicable se hará siempre con arreglo a la ley española art. 12.1 del Código Civil).

ii) Como consecuencia lógica de que los jueces españoles no tienen obligación de conocer el Derecho extranjero, se ha exigido históricamente la prueba del mismo, de forma que en este extremo el Derecho recibe un tratamiento similar al que reciben los hechos, pues debe ser objeto de alegación y prueba, siendo necesario acreditar no sólo la exacta entidad del Derecho vigente, sino también su alcance y autorizada interpretación. Por ello, el segundo párrafo del artículo 281.2 de la Ley de Enjuiciamiento Civil exige la prueba de "su contenido y vigencia», si bien, de acuerdo con el principio de adquisición, la Ley de Enjuiciamiento Civil no pone la prueba a cargo de "la persona que invoque el derecho extranjero".

iii) Si de acuerdo con la norma de conflicto española es aplicable el Derecho extranjero, la exigencia de prueba del mismo no transforma el Derecho extranjero, en cuanto conjunto de reglas para la solución de conflictos, en un simple hecho. Esto trae consigo varias consecuencias [...]. La segunda, que es la que aquí nos interesa, que el tribunal no queda constreñido, como en la prueba de hechos en los litigios sobre derechos disponibles, a estar al resultado de las pruebas propuestas por las partes, sino que puede valerse de cuantos medios de averiguación estime necesarios para su aplicación. Así lo permite el último inciso final del art. 281.2 de la Ley de Enjuiciamiento Civil [...].

iv) El empleo de los medios de averiguación del Derecho extranjero es una facultad, pero no una obligación del tribunal. No puede alegarse como infringido el art. 281.2 de la Ley de Enjuiciamiento Civil porque el tribunal no haya hecho averiguaciones sobre el Derecho extranjero.

v) La consecuencia de la falta de prueba del Derecho extranjero no es la desestimación de la demanda, o la desestimación de la pretensión de la parte que lo invoca, sino la aplicación del Derecho español. Así lo ha declarado reiteradamente esta Sala, en las sentencias citadas, y asi lo ha declarado el Tribunal Constitucional en su sentencia 155/2001, de 2 de julio, como exigencia derivada del derecho a la tutela judicial efectiva que establece el art. 24 de la Constitución.

Nota. 1. Anotamos un supuesto que podría haber servido para reflexionar sobre la aplicación del art. 12 del Convenio de Roma sobre ley aplicable a las obligaciones contractuales (y de rebote sobre el art. 14 del Reglamento Roma I, que no es aquí aplicable por cuestiones temporales). No obstante el devenir procesal derivó por otros 
derroteros. Los hechos, sumariamente descritos son los siguientes: en 2002 y 2003 los cónyuges codemandados (junto con una sociedad de la que era única socia y administradora la esposa), ambos de nacionalidad holandesa, suscribieron en los Países Bajos dos préstamos con el prestamista, también holandés y amigo de la familia, para la financiación de un proyecto inmobiliario en Girona. Los fondos fueron utilizados para la adquisición de diversos inmuebles en nuestro país. En 2005, el prestamista celebró un contrato de cesión con el demandante en el proceso principal, por el que le cedía los referidos créditos, sometiendo dicho contrato de cesión a la ley de los Países Bajos y a los tribunales de 's-Hertogenbosch. El pleito versa sobre la reclamación del cesionario a los deudores cedidos del principal y los intereses devengados (que eran de un 33 y un 24 por cien de interés anual, tal cual se había pactado). Parte de la defensa de uno de los codemandados es que la ley aplicable es la española y no la holandesa y que ni cabe la reclamación de intereses sobre los intereses ni el interés fijado puede ser admisible por ir contra la Ley de usura.

Mientras que en primera instancia se desestimó la demanda por falta de legitimación pasiva de los demandados y — se dice- como argumento de refuerzo la competencia de los tribunales holandeses pactados, en apelación, se estima, considerando aplicable la ley holandesa tanto a los contratos de préstamo cuanto al contrato de cesión, en virtud del art. 10.5 del CC y 4 del Convenio de Roma. No obstante también se aplica la ley sustantiva española a determinados aspectos del litigio.

La sentencia resulta de interés, además de por omitir un correcto análisis de las relaciones que convergen en una cesión de créditos (2), por dar por buena la interpretación peculiar que hace la Audiencia Provincial sobre la alegación y prueba del Derecho extranjero (3) y por sentar lo que considera la doctrina sobre el tema (4).

2. En el razonamiento del fallo se omite cualquier tipo de referencia específica a las normas de conflicto aplicables al caso, salvo para desestimar la infracción de las alegadas por los recurrentes (arts. 1, 10.5 y 9 y 12.6 del Código Civil, y arts. 3, 4 y 8 del Convenio de Roma). Se trata de una práctica no inhabitual la del amontonamiento de normas de conflicto de origen autónomo y de origen convencional o institucional sin distinguir para nada sus respectivos ámbitos de aplicación. Aquí, además, tiene la agravante de que no aparece la concreta regla que regularía la pretensión deducida en la demanda: el art. 12.2 del Convenio de Roma ( La ley que rija el crédito cedido determinará el carácter transferible del mismo, las relaciones entre el cesionario y el deudor, las condiciones de oponibilidad de la cesión al deudor y el carácter liberatorio de la prestación hecha por el deudor»). El aspecto más controvertido, el de la necesidad de comunicación de la cesión a los deudores, se aborda más como una cuestión de hecho que como una condición jurídica, dando ésta por supuesta. La Audiencia Provincial mezcla ambos temas, señalando que «tanto si se aplicara el Derecho holandés... como si se aplicara el Derecho español... la cesión fue válida y obligaba a los demandados frente al cesionario del crédito». En la práctica, los datos parecen apuntar que efectivamente sólo la ley holandesa estaba en juego por virtud bien del art. 3 del Convenio de Roma, para el contrato de cesión, bien del art. 4 para los contratos de crédito, y no por el hecho de haberse celebrado estos últimos en Holanda como afirma la Audiencia: no se sabe, realmente de dónde extrae tal conclusión que ni deriva del Convenio de Roma ni del art. 10.5 CC que cita (del que antes de la ley del lugar de celebración se tomaría la de la nacionalidad común de los contratantes). En todo caso, la delimitación de las respectivas relaciones implicadas no se hace en ningún momento.

3. En la misma línea de indefinición está la afirmación que la Audiencia hace, y el TS no corrige, según la cual se desestima la defensa de los demandados que pre- 
tendían la aplicación de la Ley de Usura, dado que no habían probado que en Países Bajos existiese una ley similar. Aunque el supuesto no es claro en relación con cuál fue la concreta prueba del Derecho holandés que se hizo en el proceso, el argumento es claramente falaz. Que no se pruebe que en Países Bajos hay una ley similar a la española que ampararía (presuntamente) la posición jurídica de los demandados no significa que pueda desestimarse su defensa. Ello sólo es posible si efectivamente la prueba positiva de la ley holandesa es contraria a esa pretensión. La falta de prueba de dicha ley (en sentido positivo o, como señala la Audiencia, negativo) conduciría siguiendo la doctrina que el TS recuerda con posterioridad, a la aplicación del Derecho español. Llama la atención, en todo caso, que no se haya valorado la contrariedad con el orden público español de una normativa (bien es cierto que no sabemos si convenientemente probada) que avala intereses del 24 y el 33 por ciento, en un contrato con condiciones muy probablemente negociadas (el prestamista era persona física con el que los prestatarios tenían una relación de amistad).

4. Por último, el TS hace una síntesis de lo que él mismo denomina la «doctrina» sobre el régimen de prueba y de carga de la prueba del Derecho extranjero. Hemos hecho una reproducción de dicha doctrina en el texto seleccionado de la sentencia, por lo que tan sólo haremos dos precisiones y una llamada de atención. La primera precisión es que dicha doctrina es ciertamente la predominante, pero ni es la única comprensión del problema ni se corresponde con las diferentes opciones que hay en la práctica y que defienden los autores (véase, por todos, Álvarez González, S., «Aplicación judicial del Derecho extranjero: la desconcertante práctica judicial, los estériles esfuerzos doctrinales y la necesaria reforma legislativa», Revista Jurídica Española La Ley, año XXIV, Número 6287, de 4 de julio de 2005). La segunda es que el argumento constitucional que utiliza el TS tampoco es definitivo [véase GARAU SoBRINO, F., «La no-doctrina constitucional sobre la aplicación y prueba del Derecho extranjero», en Forner Delaygua, J. J., González Beilfuss, C. y Viñas Farré, R. (coords.), Entre Bruselas y La Haya. Liber amicorum Alegría Borrás, Madrid, Barcelona, Buenos Aires, Sao Paulo, Marcial Pons, 2013, pp. 429-443]. En cuanto a la llamada de atención, hay que señalar que resulta sorprendente que las soluciones de ley aplicable que derivan del desarrollo del espacio de libertad, seguridad y justicia (aquí el Convenio de Roma, pero la misma solución se daría si se tratase del Reglamento Roma I o de cualquier otro reglamento) estén supeditadas a múltiples regímenes estatales de alegación y prueba del Derecho extranjero. No es sólo denuncia de las carencias en la aplicación de las normas de conflicto que se detectan en decisiones como la que estamos anotando, sino la inexistencia de una solución uniforme que de verdad convierta en uniformes a las soluciones de cada instrumento europeo sobre ley aplicable.

Paula Paradela AREÁN

Santiago de Compostela

http://dx.doi.org/10.17103/redi.67.2.2015.3b.11

\section{PRÁCTICA ESPAÑOLA: DERECHO CIVIL INTERNACIONAL}

\subsection{Filiación: gestación por sustitución}

2015-31-Pr

FILIACIÓN.-Maternidad subrogada.-Inscripción en el Registro Civil español.-Menores nacidos en California.-Promotores cónyuges varones.-Reconocimiento de la filiación: no.-Contrariedad con orden público español: sí.-Ju- 


\section{risprudencia del TEDH.--Vulneración del derecho a la no injerencia en la vida personal y familiar: no.-Existencia de vías alternativas al reconocimiento.}

Preceptos aplicados: Art. 8 del CEDH; arts. 10.2, 14, 18 y 24 de la CE; art. 10 de la Ley de Técnicas de Reproducción Asistida; 176, 177 del CC.

Auto TS (Sala de lo Civil, Pleno) de 2 de febrero de 2015. Ponente. Rafael Saraza Jimena.

\section{F.: Aranzadi Westlaw, RJ, 2015/141.}

[...] el ordenamiento jurídico español, y así lo afirmó nuestra sentencia, prevé que respecto del padre biológico es posible la determinación de filiación paterna; $y$, en todo caso, si los comitentes y los niños efectivamente forman un núcleo familiar "de facto" (lo que es muy posible pero no ha sido el objeto del recurso, pues los demandados han fundado su oposición a la demanda del Ministerio Fiscal en la procedencia de transcribir las actas de nacimiento de California tal como alli fueron extendidas), nuestra sentencia acuerda que debe protegerse legalmente, en su caso mediante la adopción [...].

En España, la sentencia de esta Sala acordó que sólo se anulara la mención a la filiación de los menores en tanto se determinaba la filiación biológica paterna y también, en su caso, la filiación que fuera acorde con la situación familiar "de facto" (por ejemplo, mediante la adopción), de modo que, una vez quede determinada la filiación biológica respecto del padre biológico y la filiación por criterios no biológicos respecto del otro cónyuge (o respecto de ambos, si ninguno de ellos fuera el padre biológico), tendrán la nacionalidad española y podrán heredar como hijos [...].

La cuestión decisiva es que lo que determina la relación de filiación, esencial para establecer la identidad del menor, según las normas de orden público del ordenamiento español actualmente vigentes porque el legislador ha entendido que es lo más adecuado para proteger el interés del menor, es la filiación biológica [...] y el establecimiento de lazos filiales como consecuencia de la existencia de un núcleo familiar de facto en el que estén integrados los menores, el progenitor biológico y su cónyuge, como por ejemplo los derivados de la adopción [...].

No deben descontextualizarse expresiones aisladas de las sentencias del Tribunal de Estrasburgo. Los párrafos 75 y 78 de la sentencia del caso L. y 96 y 99 de la del caso M. no afirman que cualquier afectación a la filiación del menor suponga una vulneración de su derecho a la vida privada, sino que tal afectación existe "en estas condiciones del Derecho positivo [francés]», que consisten, como se ha visto, en la absoluta imposibilidad de que el ordenamiento jurídico francés reconozca cualquier vínculo de filiación entre los comitentes y el niño [...].

Nuestra sentencia permite que la identidad de los menores quede debidamente asentada mediante el reconocimiento de la filiación biológica paterna y la formalización de las relaciones existentes si hubiera un núcleo familiar "de facto» entre los comitentes y los niños, como parece que existe. Y no sólo lo permite, sino que acuerda instar al Ministerio Fiscal para que adopte las medidas pertinentes en ese sentido para la protección de los menores.

Nota. 1. La gestación por sustitución es uno de los temas que más novedades está produciendo en los últimos tiempos en DIPr. Prueba de ello es el espacio que viene ocupando en los más recientes números de esta Jurisprudencia y el hecho de que siga haciéndolo en el presente a través del Auto del TS español de 2 de febrero enero de 
2015. Se trata de la última respuesta judicial — por el momento- al caso de mayor trascendencia en España, del que también aquí se ha dado cuenta en sus distintas entregas (REDI, 2009, pp. 215-219, con nota de QuiÑONEs EscÁMEZ, A.; REDI, 2012-1, pp. 213-216, con mi nota; y REDI, 2014-2, pp. 273-277, también con mi nota).

Se trata de un auto que resuelve el incidente de nulidad contra la STS de 6 de febrero de 2014. Recordemos que, simplificando a efectos descriptivos, el TS había rechazado el recurso de casación contra la negativa a inscribir nacimiento y filiación de dos menores nacidos mediante gestación por sustitución en California, poniendo énfasis en la contrariedad con el orden público de tal tipo de filiación. Tras la STS, el TEDH dictó sus, también trascendentes sentencias en los casos Mennesson y Labasse (TEDH de 26 de junio de 2014, asunto 65192/11, Mennesson c. Francia, y TEDH de 26 de junio de 2014, asunto 65941/11, Labassee c. Francia, REDI, 2015-3-Pr, con nota de Jiménez Blanco, P.; véase también, sobre ellas, Presno Linera, M. A. y Jiménez BlanCo, P., «Libertad, igualdad, ¿maternidad? La gestación por sustitución y su tratamiento en la jurisprudencia española y europea», Revista Española de Derecho Europeo, 2014, núm. 51, pp. 9-44).

Las sentencias del TEDH justificarían, según los interesados, la revocación de dicha sentencia (también JiménEz Blanco, P., op. cit., pp. 238-241, p. 240) y, consecuentemente, la estimación del recurso de casación y el mantenimiento de las inscripciones de nacimiento y filiación aceptadas por la DGRN en 2009. Sin embargo, el TS les dice a los recurrentes que las nuevas sentencias del TEDH no son extrapolables a su caso. Esto significa implícitamente que la postura del TS en la que declaraba contraria al orden público español la gestación por sustitución sigue, al menos para los casos similares al enjuiciado, vigente.

2. El silogismo básico del TS es que la esencia de la vulneración del art. 8 del CEDH en el caso de las Sentencias del TEDH que condenaron a Francia no se encontraba en el rechazo al reconocimiento de los efectos de la filiación existente en el extranjero entre nacidos y comitentes, sino en la absoluta imposibilidad de que la filiación natural de los niños pudiese establecerse a través de otros medios. En Francia, el mero hecho de haber recurrido a la maternidad subrogada inhabilitaba cualquier otro título de legitimación de la filiación. Por el contrario, aduce el TS, en España la situación es diferente, puesto que no se excluye la posibilidad de determinación de la paternidad biológica. El TS se agarra a este hecho para negar la analogía entre los casos resueltos por el TEDH y el que resuelve y para reafirmar que la Sentencia española respeta el derecho a la vida privada de los menores y a la determinación de su identidad. La clave, repito, estaría en la posibilidad de establecer la filiación biológica paterna, con una consiguiente (aunque no necesaria) adopción por parte del cónyuge. Además, añade el TS, la situación de incertidumbre que esta determinación conlleva en España no sería equiparable al caso francés, que mereció la condena del TEDH.

Se trata de consideraciones que en modo alguno pueden ser tachadas de arbitrarias. Ciertamente, se fundamentan en un determinado concepto de interés superior del niño y, sobre todo, en un concreto tipo de maternidad subrogada: aquél en que existe un vínculo biológico entre padre de intención y nacidos. Uno de los supuestos más frecuentes, hay que decir, pero no el único.

Son consideraciones que tienen cierto peso y que, además, no son aisladas. La STF alemán de 10 de diciembre de 2014 (http://www.bundesgerichtshof.de, con un resumen comentado en inglés de REIS, D., "German Federal Court of Justice on Surrogacy and German Public Policy», en www.conflictoflaws.net, entrada de 4 de marzo de 2015, 
post de Jan von HEIN) aun llegando a una solución contraria a la del TS, se mueve en una línea en la que huye de generalizaciones (a favor o en contra de la gestación por sustitución) y se centra en el caso concreto. La sentencia alemana (al contrario que la STS de 2014, pero al igual que el ATS que ahora comentamos) realiza un escrutinio in concreto del orden público apoyándose en las circunstancias específicas de la situación: madre gestante soltera y uno de los comitentes padre biológico, formando pareja registrada con otro varón. Este es un caso en el que de conformidad con la ley alemana el reconocimiento voluntario de paternidad sería posible respecto del padre biológico, mientras que, mediando, como así fue, consentimiento posterior al parto de la madre gestante, el resultado de reconocer la relación paternofilial respecto del conviviente, no podría vulnerar el orden público cuando en Alemania la adopción del hijo del conviviente registrado es perfectamente posible (se habla de adopciones sucesivas por uno y otro conviviente como regla consagrada por el Tribunal Constitucional Alemán).

Resulta claro que no se puede obviar el resultado final: en España el TS considera que no se atenta a la vida personal y familiar de los nacidos porque tienen otras posibilidades (distintas al reconocimiento de la filiación tal cual deriva de las decisiones extranjeras) para acreditar su real filiación y acomodarse a su real situación familiar. En Alemania, precisamente porque existen esas posibilidades de acreditar la real filiación y acomodar la situación familiar de hecho a una situación familiar de Derecho, se reconoce aquella filiación. Los dos tribunales superiores tuvieron en cuenta las sentencias del TEDH. Con soluciones diversas, pero tomando partido $-\mathrm{y}$ razonando de forma no arbitraria - sobre lo que realmente el TEDH dejó sin cerrar.

3. Efectivamente, las respuestas del TEDH fueron también matizadas y dejaron temas abiertos. En un reciente documento de la Conferencia de La Haya (www.hcch. net, HAGUE CONFERENCE ON PRIVATE INTERNATIONAL LAW, "The parentage / surrogacy proyect: an updating note», documento preliminar $3 \mathrm{~A}$, a la atención del Consejo de Asuntos Generales de marzo de 2015, febrero de 2015) se plantean dos ejemplos que generan otras tantas dudas: en primer lugar, qué ocurre con los supuestos en los que no existe una relación biológica entre padre y nacidos así como aquéllos en los que hay una relación genética entre la madre de intención y los nacidos; en segundo término, los casos, como el resuelto por el Auto TS que anotamos, en los que existen vías alternativas al mero reconocimiento para establecer la filiación (véanse los puntos 8.a y $8 . b$ del referido documento). El TS da una respuesta posible a esta indeterminación (en sentido contrario a otras en otras latitudes: véase la nota a pie 31 del Documento de la Conferencia de La Haya). Aventuro que no será su dictamen el último en el caso que nos ocupa.

4. Diré, para concluir, que la respuesta del Auto TS no creo que pudiera verse comprometida por la Sentencia del TEDH de 27 de enero de 2015, asunto 25358/12, Paradiso et Campanelli c. Italia, que, aun teniendo como telón de fondo un supuesto de maternidad subrogada en el que ni la madre ni el padre de intención tenían relación biológica con el nacido, no entró en el fondo de los asuntos aquí tratados.

Por otro lado, el Auto anotado también tiene su voto particular. A pesar de los esfuerzos de la mayoría por reconducir el fallo a un análisis técnico, los magistrados disidentes son los mismos que en la Sentencia contra la que se interpuso el recurso de nulidad. Y curiosamente, contrariamente a lo ocurrido con el voto particular a la Sentencia, los magistrados disidentes han optado por una de las posibles consecuencias de las sentencias del TEDH: la generalización y la maximización de la posibilidad (necesidad) de reconocimiento. Según el voto particular, de lo que se trata es de resolver 
los problemas de los niños nacidos mediante gestación por sustitución y en función de su supremo interés y el derecho a su identidad debería haberse estimado el recurso.

Probablemente se trate este auto del TS de un último acto de reivindicación antes de asumir el peso imparable de las exigencias del CEDH: todo lo que el TS dice es cierto; en el fondo, se achaca a los promotores que no han sabido pedir lo que sí se les podía dar. Y éstos, a buen seguro seguirán defendiendo en las «instancias» que les quedan (TC, TEDH) que no es lo mismo el reconocimiento de la filiación derivada de la gestación por sustitución, que las alternativas de legitimación de la filiación para el padre biológico y la adopción subsiguiente por parte del cónyuge. La saga probablemente continuará.

Santiago Álvarez GonZÁLEZ

Universidad de Santiago de Compostela http://dx.doi.org/10.17103/redi.67.2.2015.3b.12

\subsection{Procesos matrimoniales}

2015-32-Pr

MATRIMONIO: Disolución del vínculo matrimonial.-_Responsabilidad parental.-Alimentos.-Competencia judicial internacional.-Ley aplicable.-Remisión a un Estado plurilegislativo.

Preceptos aplicados: arts. 3, 8 y 12.1 y 12.4 del Reglamento (CE) núm. 2201/2003; art. 8 del Reglamento (UE) núm. 1259/2010; arts. 3 y 15 del Reglamento (UE) núm. 4/2009; art. 15 del Convenio de La Haya de 1996; arts. 3 y 4.3 del Protocolo de La Haya de 2007; art. 22.1 de la LOPJ.

Sentencia de la AP de Barcelona (Sección 12. a), de 15 de enero. Ponente: Elena Farré Trepat.

\section{F.: Aranzadi Westlaw, JUR 2015/76317.}

Por el hecho de tener ambas partes su residencia habitual en Barcelona la competencia para la declaración de divorcio corresponde a los tribunales españoles, y concretamente a los tribunales de Barcelona, en virtud de lo dispuesto en el art. 3.1 a) del R.2201/2003 y 769 LEC. La ley aplicable al divorcio es la española, conforme a lo dispuesto en el art. 8 del Reglamento 1259/2010 del Consejo de 20 de diciembre de 2010.

Los tribunales españoles también son competentes para dirimir las medidas personales, derivadas de la responsabilidad parental, referidas a los hijos menores de edad. En primer lugar, en relación con los tres menores que residen en Barcelona [...]. La competencia de los tribunales españoles en relación con el menor que actualmente se encuentra residiendo en China con sus abuelos maternos se desprende de lo dispuesto en el art. 12.1, del mismo texto legal, por el hecho de que a pesar de que el menor no reside en Barcelona, sino en China al cuidado de los abuelos maternos, puede considerarse que en este caso ambos progenitores continúan ejerciendo la responsabilidad parental respecto del mismo, adoptando las decisiones inherentes a la misma y con la previsión de que en un futuro pueda trasladarse a Barcelona. No se ha cuestionado por parte de los progenitores la competencia de los tribunales españoles para la adopción de todas las medidas referidas a todos los hijos, y la adopción de estas medidas responde al interés 
del menor, como se concluye de la aplicación de la presunción establecida en el mismo art. 12.4 del Reglamento 2201/200.

La competencia respecto de la obligación de abonar alimentos para los hijos, se regula en el art. 3 del Reglamento 4/2009 [...].

Tanto en relación con las medidas personales como respecto de la obligación de alimentos es aplicable la ley española, conclusión que se alcanza, por la aplicación de lo dispuesto en el art. 15 del CH de 1996 y por la aplicación de lo dispuesto en el art. 15 del Reglamento 4/2009, que remite al protocolo de La Haya de 23 de noviembre de 2007, sobre ley aplicable a las obligaciones alimenticias».

Nota. 1. La AP de Barcelona aborda otro caso en el que una vez más se demuestran los conocimientos en DIPr de su Sección 12. ${ }^{a}$ El supuesto es simple: se trata de un divorcio de carácter contencioso entre dos nacionales chinos con residencia habitual en Barcelona. El matrimonio tiene cuatro hijos de los cuales tres residen en España y uno sigue residiendo en China con sus abuelos maternos. Las partes están conformes con todos los aspectos resueltos excepto en la cantidad asignada en concepto de manutención a los menores. Es el progenitor quien apela la decisión con el propósito de reducir la cantidad.

2. Como ya sucedería en otras decisiones, aunque las cuestiones relativas al DIPr no son objeto de controversia, la AP Provincial de Barcelona (Sección 12. ${ }^{a}$ ) se centra en analizar tales aspectos partiendo de una explicación en torno a los instrumentos que de distinta fuente fijan tanto su competencia judicial internacional para pasar después a centrarse en aquellos que determinan el derecho aplicable.

3. Pues bien, a nuestro juicio hace una reflexión y aplicación acertada en relación con la normativa tanto para la determinación de la competencia judicial internacional como en referencia a la ley aplicable en lo que hace a la disolución del vínculo. Aplica para la competencia judicial el art. 3.1.a) del Reglamento (CE) núm. 2201/2003 y para la determinación de la ley aplicable el Reglamento (UE) núm. 1259/2010 estableciendo que el vínculo se disolverá por la ley de la residencia habitual de las partes, una vez descartada, como sostiene el Tribunal, el uso de la autonomía de la voluntad por las partes.

4. El aspecto de mayor interés es la determinación de la competencia judicial internacional para decidir sobre la responsabilidad parental del menor cuya residencia habitual no se encuentra en España ni en otro EM sino en China. El Tribunal en este supuesto aplica la previsión del art. 12 del Reglamento (CE) núm. 2201/2003 que introduce un foro por conexidad, permitiendo que la autoridad competente en materia de divorcio pueda conocer también en relación con la responsabilidad parental de los hijos cuya residencia habitual se sitúa en el territorio de un Estado distinto. Hay que resaltar que el art. 12.1 del Reglamento (CE) núm. 2201/2003 no delimita su ámbito de aplicación personal a los menores con residencia habitual en otro EM [a diferencia de su antecesor Reglamento (CE) núm. 1347/2000 que requería para aplicar el foro por conexidad que la residencia del menor estuviera situada en otro Estado miembro]; en consecuencia la aplicación de la normativa de fuente europea se extiende a menores con residencia en terceros Estados (muy crítico con la eficacia que en la práctica tendrán las decisiones adoptadas en aplicación el art. 12.1, DE BOER, Th. M. «What we should not expect from a recast of Brussels IIbis Regulation», NIPR on Brussels II revision, 2015, pp. 10-19). En el caso que nos ocupa China no ha ratificado el Convenio de La Haya de 1996, y por tanto la AP ni se cuestiona la posible colisión entre normas y en su caso en cuál de ellas habría de fundamentar la competencia. 
5. El lugar de residencia habitual del menor es el foro de competencia principal y responde al criterio de proximidad razonable; en el caso del foro por conexidad se trata de un tribunal que aunque no sea el más próximo sí puede ser el conveniente para resolver tanto el divorcio como la responsabilidad parental. Para ello el art. 12 del Reglamento (CE) núm. 2201/2003 requiere que el tribunal revise el cumplimiento de unas condiciones sobre las cuales es interesante detenernos, como hace la AP. Hay un número ya destacable de decisiones españolas que como en este supuesto han aplicado este foro por conexidad. Las condiciones que conforme al mencionado precepto han de cumplirse son: $1 .^{\mathrm{a}}$ ) que al menos uno de los cónyuges ejerza la responsabilidad parental sobre el menor. Este dato se da por hecho en este caso por parte de la AP de Barcelona, cuando afirma que los cónyuges ejercen la responsabilidad parental adoptando las decisiones inherentes a la misma. En la práctica este requisito se ha entendido cumplimentado cuando es uno de los progenitores quien reside con el menor y de forma efectiva ejerce los derechos y deberes contenidos en el concepto de responsabilidad parental [AP de Salamanca (Sección 1. a) Sentencia de 29 de noviembre de 2006 JUR/2007/144148]. Pero en el caso objeto de este comentario se trata de un menor de cuyo cuidado en China se encargan sus abuelos $¿$ se puede decir que el ejercicio efectivo de la responsabilidad parental lo llevan a cabo los progenitores? (contrarios a que los tribunales adquieran la competencia en estos casos concretos en el que podría enmarcarse el supuesto comentado se muestran CAlvo CARAVACA, A. L. y CARRAScoSA GonZÁlez, J., Derecho internacional privado, vol. II, Granada, Comares, 2014-2015, pp. 408-409). 2. ${ }^{\mathrm{a}}$ ) La segunda condición más compleja de producirse en el marco del art. 12.1 es la aceptación de la competencia de forma expresa o de cualquier forma inequívoca por los cónyuges. En algunos de los pronunciamientos los órganos judiciales ni reparan en el cumplimiento in casu de las condiciones [Auto de la AP de Barcelona (Sección 12. ${ }^{a}$ ) de 20 de diciembre de 2010, AC 2011/225]; en otros se detienen para interpretar que efectivamente se ha cumplido el acuerdo [citada AP de Salamanca; AP de Teruel (Sección 1. a) Auto de 25 de noviembre de 2010, JUR 2011/63840] o por el contrario para declarar la falta de competencia por su incumplimiento [Auto de la AP de Valencia (Sección 10. ${ }^{\text {a) }}$ de 14 de octubre de 2010, JUR 2010/72125]. En el caso de la AP de Barcelona la no oposición a la competencia por parte del ahora apelante hace entender que el acuerdo existe; en consecuencia dicha actitud entraría dentro del concepto aceptación de la competencia por cualquier forma inequívoca recogido también en el art. 12.1. 3. ${ }^{\circ}$. La tercera de las condiciones conlleva el análisis de que la adopción de las medidas responden al interés del menor; circunstancia que en el caso resuelto por la AP de Barcelona se considera cumplido a través del apdo. 4 del art. 12 en aplicación de la presunción que en el mismo se establece; ahora bien y como ha dicho el TJUE la operatividad de la mencionada norma de competencia es excepcional y su aplicación conlleva un análisis in casu (STJUE de 12 de noviembre de 2014, Asunto C-656/13, apdo. 58, REDI, 2015-25-Pr, con nota de JimÉnEz Blanco, P.). De forma que son discutibles aquellas decisiones en las que se asume el conocimiento de los aspectos relativos a la responsabilidad parental en base al citado precepto pasando por alto o sin argumentar su correspondencia con el interés del menor que sólo se preserva analizando en cada caso si la prórroga de la competencia responde a dicho interés (como ejemplo de una aplicación muy cuidadosa haciendo un verdadero esfuerzo de interpretación [citada AP de Salamanca (Sección 1. a) Sentencia de 29 de noviembre de 2006].

6. En lo que hace a la competencia en materia de alimentos, la AP se refiere al art. 3 del Reglamento (UE) núm. 4/2009, en particular al foro de la residencia habitual del demandado. En esta decisión, a diferencia de otras, distingue y concreta el foro en el que basa su competencia. 
7. En relación con la ley aplicable, la AP se refiere de forma correcta tanto al Convenio de La Haya de 1996 en responsabilidad parental, como en materia de alimentos al Protocolo de La Haya de 2007; pero otra vez se olvida de hacer el recorrido jurídico que lleva a la ley catalana como ley española aplicable en ambas materias. Esta falta de argumentación ha sido denunciada en distintas notas publicadas [ejemplo GoNZÁlez BeILfuss, C., REDI, vol. 67, 2015, núm. 1, pp. 272-275; ÁlvAREZ GoNZÁLEZ, S., REDI, vol. LXV, 2013, núm. 2, pp. 323-326; QuinZÁ REDondo, P., REDI, vol. LXVI, 2014, núm. 2, pp. 270-273]; al menos en este caso omite la referencia a la aplicación del Derecho catalán como resultado de los arts. 14 del Estatuto y 111.3.1 del CC de Cataluña.

8. En cualquier caso, esta última referencia no empaña el buen conocimiento que de los instrumentos jurídicos aplicables a las relaciones privadas internacionales

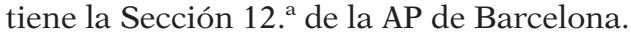

Mónica HerRanz Ballesteros*

UNED

http://dx.doi.org/10.17103/redi.67.2.2015.3b.13

2015-33-Pr

PROCESO DE DIVORCIO EN ESPAÑA.-Aplicación de la ley búlgara.-Concepto de alimentos.-Diferencia entre pensión de alimentos y pensión compensatoria.-Denegación del retorno de los menores.-Competencia en materia de responsabilidad parental: utilización del art. 15 del Reglamento 2201/2003.

Preceptos aplicados: Reglamento 2201/2003; Convenio de La Haya de 1980 sobre sustracción internacional de menores; Reglamento 4/2009 y art. 107 del Código civil.

Sentencia del Tribunal Supremo (Sala de lo Civil) de 23 de marzo de 2015. Ponente: José Antonio Seijas Quintana.

\section{F.: Aranzadi Westlaw, RJ 2015/1156.}

"La sentencia recurrida da adecuada respuesta a la petición de declaración de culpabilidad, a la que se asocia la pensión alimenticia, y lo hace para desestimarla. En primer lugar, porque no fue introducida en la demanda. Para pedir la declaración de culpabilidad del esposo o negarla de sí misma, dice la sentencia, y no ha sido contradicho, debió hacerse mediante reconvención, según la norma procesal española, esto es el artículo 770.2. ${ }^{a}$ LEC , puesto que el tribunal no se ha de pronunciar de oficio, según se desprende del artículo 49.3 del Código de Familia búlgaro. En segundo, porque, en cualquier caso, lo único que se desprende de la prueba es que tras la crisis matrimonial ambas partes han reanudado su vida sentimental, no pudiéndose culpabilizar de la ruptura a ninguna de ellas».

"La sentencia concede alimentos. La pensión que reclama la demandante, señala la sentencia, está regulada en el artículo 145 del Código de Familia búlgaro. Se trata de una pensión alimenticia, con un plazo máximo de tres años, salvo mayor duración por motivos excepcionales. Tampoco hay incongruencia».

* Esta nota es parte del Proyecto: «Reglamentación de las crisis matrimoniales internacionales en el Derecho español y de la Unión Europea», Programa Estatal de Fomento de la Investigación Científica y Técnica de Excelencia, Subprograma Estatal de Generación del Conocimiento, en el marco del Plan Estatal de Investigación Científica y Técnica y de Innovación 2013-2016 DER2014-54470-P. 
"La pensión que reclama la demandante está en el artículo 145 del CFB. Se trata de una pensión alimenticia que se concede conforme a las exigencias de este derecho y se cuantifica a partir de una justa ponderación de los recursos de ambos esposos, que no han sido cuestionados. Según los hechos probados de la sentencia, no combatidos en debida forma, la esposa carece de ingresos y la capacidad económica del esposo es muy importante, "empresario internacional en el sector turístico e inmobiliario. No resulta posible, por el entramado de sociedades instrumentales, algunas en paraísos fiscales, cifrar sus ingresos reales, pero el montante de la propia hipoteca antes señalado, los gastos del inmueble (unos 3.000 euros mensuales), los viajes de la familia, etc. llevan a la conclusión de que el esposo puede atender sobradamente las necesidades de la esposa a tenor de los gastos acreditados».

\section{Sentencia de la Audiencia Provincial de Barcelona (Sección 12. ${ }^{\mathrm{a}}$ ) de 18 de di- ciembre de 2013. Ponente: Joaquín Bayo Delgado.}

\section{F.: Aranzadi Westlaw, JUR 2014/20409.}

"Dado que la residencia habitual de los menores estaba en España antes de su retención ilegal en Bulgaria ...y que el no retorno se debe a la excepción dicha del artículo 13 del Convenio de 1980 y no a la inexistencia de sustracción ilegal ..., la competencia para los aspectos de responsabilidad parental correspondía en el momento de la demanda a los tribunales españoles según el artículo 8 del Reglamento (CE) 2201/2003, y continúa correspondiendo por perpetuatio iurisdictionis hasta que se alcance una sentencia firme».

«Hasta el momento en que la autoridad judicial búlgara se manifieste sobre su competencia, las medidas sobre guardia, alimentos y domicilio de los menores adoptadas en la sentencia de primera instancia se mantendrán vigentes, y quedarán sin efecto si los tribunales búlgaros admiten su competencia. En caso contrario, procederá resolver sobre la apelación de esos aspectos».

Nota. 1. La Sentencia del Tribunal Supremo responde a dos recursos, un recurso extraordinario por infracción procesal y un recurso de casación, interpuestos por el marido en un conflictivo caso de divorcio. Ambos recursos son desestimados por el Tribunal Supremo. El origen del caso se encuentra en la Sentencia del Juzgado de Primera Instancia núm. 16 de Barcelona, de 25 de octubre de 2012, que dictó sentencia de divorcio de una pareja de búlgaros que se habían casado en Bulgaria y residían en Barcelona. Tienen tres hijos, de los cuales la mayor, de 17 años, estudia en Londres y los otros dos residen con sus padres. En lo que se refiere al matrimonio, la sentencia declara el divorcio, la disolución del régimen de bienes y una pensión a favor de la mujer. En lo que se refiere a los hijos, establece una custodia compartida, por periodos de dos semanas que se deberá ejercer en Sofía, debiendo el padre abandonar el domicilio que ocupa en esa ciudad cuando le corresponda a la madre, además de asumir el padre todos los gastos de los menores. La madre sigue residiendo en la casa de Barcelona.

Contra dicha sentencia interpusieron recurso de apelación tanto el marido como la mujer, que fue decidido por la Sección 12. a de la Audiencia Provincial de Barcelona mediante la interesante Sentencia de 18 de diciembre de 2013, que utiliza prolijamente los instrumentos de la Unión Europea y los Convenios internacionales, con la soltura que caracteriza a esta Sección. En efecto, una parte de ella es la que es objeto de la Sentencia del Tribunal Supremo, pero tiene otra parte importante, todavía no 
resuelta definitivamente por lo que se indicará. En realidad, pues, hay dos cuestiones diferentes, una referida a los hijos y otra al divorcio de los padres.

2. Tras unas vacaciones en Bulgaria, la madre no puede traer los niños a Barcelona porque el padre retiene los pasaportes y la autorización notarial. El Tribunal de Sofía entiende que ha habido retención ilegal, pero que se da la excepción al retorno prevista en el art. 13 del Convenio de La Haya de 1980, en el sentido que hay integración familiar, escolar y social, los niños expresan su deseo de quedarse e, incluso, el mismo hecho de que la madre debiera de desplazarse a Sofía en la quincena que le corresponde estar con los niños, como dice la Sentencia de la Audiencia. Pero, como también dice esta sentencia, el tribunal búlgaro omitió el trámite previsto en el art. 11.6 del Reglamento 2201/2003, en el sentido de comunicar dicha resolución, ya que son los tribunales españoles los que tienen la última palabra sobre el retorno. Vistas las circunstancias, la Audiencia confirma la decisión de no retorno de los dos menores.

Ello no es óbice, no obstante, para que la Sentencia de la Audiencia mantenga la competencia de los tribunales españoles conforme al art. 8 del Reglamento 2201/2003 y continúe correspondiéndoles hasta que haya una sentencia firme, ya que, por el momento, sólo se trata de medidas provisionales, apoyándose para ello en la Sentencia del TJUE de 1 de julio de 2010 en el asunto C-211/10 PPU, Povse (en la REDI, 201020-Pr, con nota de Magallón, N., y en la Revista Jurídica de Catalunya, 2011, núm. 1, pp. 286 y ss). Pero la Audiencia realiza dos manifestaciones de interés. La primera, el rechazo de que la competencia de los tribunales españoles derive del art. 12 del Reglamento, ya que no hay prórroga de competencia por acumulación al divorcio al no haber aceptado el padre la competencia. La segunda, la apreciación de la existencia de las condiciones que establece el art. 15 del propio Reglamento que justificarían la inhibición de los tribunales españoles a favor de los tribunales búlgaros (en cuanto lugar de la residencia habitual de los menores, nacionalidad de los menores y residencia habitual de uno de los titulares de la responsabilidad parental), una disposición que sólo muy excepcionalmente se utiliza. De ahí que decida remitirla, a través de la Autoridad Central, al Tribunal de Sofía "para que se manifieste si asume la jurisdicción para los aspectos de responsabilidad parental y alimentos de los menores», ya que los tribunales de Sofía deberían conocer en tal caso de la acción de alimentos vinculada a la de responsabilidad parental, en virtud del art. 3.d) del Reglamento 4/2009. Como indica la sentencia de la Audiencia, mientras tanto se mantendrán las medidas sobre guarda, alimentos y domicilio de los menores adoptadas por la sentencia de primera instancia, pero quedarán sin efecto si los tribunales búlgaros admiten su competencia. Si, por el contrario, no la admiten, es cuando la Audiencia resolverá en apelación sobre dichas cuestiones. Según las últimas noticias, hasta la fecha aún no han respondido los tribunales búlgaros.

3. La otra parte del asunto se refiere a las cuestiones relativas al divorcio y sus consecuencias. La sentencia de la Audiencia empieza por recordar la competencia de los tribunales españoles y el hecho de que la determinación de la ley aplicable se hará por el art. 107.2 del Código civil, ya que en la fecha de la demanda aún no estaba en vigor el Reglamento 1259/2010.

Una parte de la sentencia de la Audiencia de Barcelona es objeto de recurso del marido ante el Tribunal Supremo y consiste en un recurso extraordinario por infracción procesal. El recurso se refiere tanto al cauce procesal utilizado respecto a la petición de declaración de culpabilidad como en relación con la pensión alimenticia. 
En lo que se refiere a la declaración de culpabilidad, dice la Sentencia que, tanto la petición de culpabilidad del esposo como la negativa de ella debió hacerse mediante reconvención, de acuerdo con el art. 770.2. ${ }^{a}$ de la LEC y no de acuerdo con la forma del art. 49.3 del Código de familia búlgaro. En definitiva, se trata de una aplicación simple de la regla lex fori regit processum. En cuanto al fondo, quizás de forma innecesaria, se refiere la sentencia a que no hay culpa de ninguno de ellos, pues ambos han reanudado su vida sentimental.

En lo que se refiere a la pensión de alimentos a favor de la mujer, la sentencia de la Audiencia concedió a la mujer una pensión de alimentos de 15.000 Euros al mes, considerando que el Juzgado le había concedido una pensión manifiestamente inferior al nivel que tenían antes de la ruptura y que sigue teniendo el marido. El Tribunal Supremo considera que la concesión se hizo de acuerdo con el art. 145 del Código de Familia búlgaro.

4. En el recurso de casación se alega que existe interés casacional por oposición a la doctrina del Tribunal Supremo sobre alegación y prueba del Derecho extranjero, al no haber aplicado correctamente el Derecho búlgaro. Entiende el marido que hay oposición a la doctrina del Tribunal Supremo por no haber aplicado correctamente el Derecho Búlgaro en los términos que resultan del Código de Familia Búlgaro vigente y citando al respecto las sentencias del Tribunal Supremo de 4 de julio de 2006 y 24 de junio de 2010. En lo que se refiere al contenido de la prestación de alimentos, entiende se produce una confusión entre lo que son alimentos y lo que sería en España una pensión compensatoria, discutiendo también la cuantía de la pensión. El Tribunal Supremo desestima también este recurso, entendiendo que la pensión que se concede está de acuerdo con las disposiciones del Código de familia búlgaro y se cuantifica de acuerdo con dicha normativa.

Alegría BORRÁS*

Universidad de Barcelona

http://dx.doi.org/10.17103/redi.67.2.2015.3b.14

\subsection{Ley aplicable a los efectos del matrimonio}

2015-34-Pr

RÉGIMEN ECONÓMICO MATRIMONIAL.-Legislación aplicable.-Matrimonios celebrados con anterioridad a la Ley 11/1990, de 15 de octubre y con posterioridad a la Constitución Española.-Laguna legal.-Autonomía de la voluntad.

Preceptos aplicados: art. 9.2 del CC en su versión anterior a la Ley 11/1990, de 15 de octubre.

Resolución DGRN, de 9 de julio de 2014. Derecho: Ilmo. Sr. Director General de la Dirección de los Registros y del Notariado, Joaquín José Rodríguez Hernández.

\section{F.: $B O E$, núm. 185, de 31 de julio de 2014.}

* Esta colaboración se enmarca en el Proyecto titulado «La aplicación de los instrumentos comunitarios en materia de Derecho internacional privado por los tribunales españoles: balance y perspectivas», financiado por el Ministerio de Economía y competitividad, Dirección General de Investigación Científica y Técnica, y con referencia DER2012-36920. 
6. El hecho de que el artículo 9. 2 del Código Civil elija el momento inicial para establecer la determinación de la ley no quiere decir que esa determinación pueda y en ocasiones deba fijarse en un momento posterior — con referencia al momento temporal inicial relevante- a fin de dotar de seguridad las relaciones de los cónyuges entre sí y con terceros.

La determinación de la ley aplicable conforme a datos fácticos no planteará problemas —inter partes - si ambos cónyuges de mutuo acuerdo consienten en la valoración. En otro caso será necesario el correspondiente pronunciamiento judicial.

7. Junto a la determinación de la ley aplicable, el Reglamento (UE) n. ${ }^{\circ}$ 1259/2010 del Consejo de 20 de diciembre de 2010 por el que se establece una cooperación reforzada en el ámbito de la ley aplicable al divorcio y a la separación judicial, del que España forma parte, establece, en su artículo 5, la elección por ambos esposos de la ley aplicable a la separación y divorcio, a fin asimismo de evitar conflictividad inter partes.

La determinación de ley, pues, no ha de confundirse, con la elección de ley prevista en la norma comunitaria.

8. No obstante, en este caso concreto concurren circunstancias especiales que debe ser valoradas. De una parte, la decisión de ambos esposos de determinar, que no elegir, pues, como se ha indicado, no sería posible una elección, entre las circunstancias más relevantes concurrentes al inicio de su matrimonio.

Entre ellas cobra fuerza la inscripción inicial en el Registro Civil consular español de su matrimonio y sobre todo el hecho de que conste, actualmente, indicado al margen de su inscripción, como está acreditado, que el matrimonio ha capitulado conforme la ley española y mutado su régimen económico matrimonial por el de participación establecido en los artículos 1431 y siguientes del Código Civil.

9. Si bien es cierto que en la lógica del sistema se encuentra la congelación inicial de efectos de matrimonio - sin perjuicio de la posibilidad de cambio de su régimen patrimonial-estableciendo su fijación en el momento de celebración del matrimonio, no lo es menos, que en el caso de los matrimonios contraídos bajo el imperio de la Ley de 1974 ha de tenerse presente que la declaración de inconstitucionalidad, como se ha indicado, no ha sido solucionada por el legislador. Por ello aunque la inconstitucionalidad no puede ser objeto de modulación en cuanto efecto automático, nada impide que la laguna legal quede voluntariamente integrada por la decisión de ambos esposos reconociendo, con carácter retroactivo al inicio de su matrimonio, la aplicación de ley española.

Siendo prueba de los hechos inscritos la inscripción - e indicación-en el Registro Civil y existiendo una laguna legal no colmada por el legislador, creada por la indicada declaración de inconstitucionalidad del último inciso de la anterior redacción del artículo 9.2 del Código Civil, ha de considerarse suficientemente acreditada la existencia de sociedad de gananciales entre los esposos.

Nota. 1. La DGRN aborda en la resolución que comentamos un tema más que conocido: el de la ley aplicable en la actualidad al régimen económico de un matrimonio celebrado con posterioridad a la vigencia de la Constitución Española, antes de que la Ley 11/1990, de 15 de octubre, eliminase el oprobio de la discriminación consagrada por el art. 9.2 surgido de la reforma del Título Preliminar de 1974 y una vez que el Tribunal Constitucional, a través de su STC 39/2002, de 14 de febrero, declaró el art. 9.2 CC contrario a la Constitución (en su Fundamento jurídico $5 .^{\circ}$ ) y remitió a la legalidad ordinaria el cómo resolver «no es a este Tribunal, sino a los órganos judiciales, a quienes les corresponde integrar, por los medios que el Ordenamiento jurídico pone a su 
disposición, la eventual laguna que la anulación del inciso del precepto cuestionado pudiera producir en orden a la fijación de un punto de conexión subsidiario» [véanse los comentarios de Rodríguez Pineau, E., «La inconstitucionalidad del art. 9.2 CC de 1974 (Comentario a la STC 39/2002, de 14 de febrero)», REDI, 2002, pp. 243-254; y de Heredia Cervantes, I., «El artículo 9.2 CC (1974) era inconstitucional (evidentemente); comentario a la STC 39/2002, de 14 de febrero de 2002», Derecho privado y Constitución, 2002, núm. 16, pp. 203-221].

El supuesto de hecho es típico, no tiene por qué ser infrecuente (tanto en el nivel internacional como en el interregional) y, por tanto, la respuesta que ofrece la DGRN es importante, si es que llega a consolidarse como línea de solución. Cumple también recordar, que la STS de 11 de febrero de 2005 había sancionado implícitamente la regla tempus regit actum y había retenido la ley de la vecindad civil del marido al tiempo de contraer matrimonio, como determinante del régimen económico matrimonial de un matrimonio celebrado en 1973 (véase sobre la misma, Diago DiaGo, M. P., AEDIPr, 2005, pp. 769-773; Magallón Elósegui, N., REDI, 2005-35-Pr) y que ésta pareció ser también la posición de la DGRN ante un supuesto - que recuerda en cierto modo al presente- en el que el Órgano Directivo, eludió conceder relevancia alguna a las afirmaciones de los cónyuges sobre la ratificación de su régimen económico matrimonial (también matrimonio celebrado antes de la vigencia de la Constitución Española: DGRN de 22 de noviembre de 2005, AEDIPr, 2006, con mi nota, pp. 1171-1173).

2. El supuesto que resuelve la DGRN versa sobre la suspensión de la inscripción sobre determinadas fincas en virtud de escritura de capitulaciones matrimoniales y de liquidación de la sociedad de gananciales. El registrador no considera que estuviera acreditado que el régimen económico del matrimonio era —antes de la escriturael de gananciales. Los cónyuges, de nacionalidad española y portuguesa, respectivamente, habían contraído matrimonio en Münser (Alemania) en 1983. El registrador considera que en virtud de lo dispuesto en el art. 9.2 del CC (en su versión actual) la ley aplicable a los efectos de este matrimonio sería la alemana (primera residencia habitual común tras la celebración) y, por tanto, el régimen económico sería el de la Zugewinngemeinschaft, o participación y comunidad diferida. La DGRN sitúa el tema en sus justos términos temporales (tras la Constitución y antes de la Ley 11/1990) y comienza valorando la posibilidad de una cierta aplicación retroactiva de esta misma ley (postura que — quizá no del todo consciente- coincidiría con la del registrador). El razonamiento a partir de este momento es confuso y errático (fin del punto 5 hasta punto 9 de la Resolución).

Errático porque tras plantear la posibilidad de un «efecto bifronte en el tiempo de la Ley 15/1990», se pasa a otras posibilidades, sin descartar aquélla ni dar ninguna razón para que ese efecto bifronte deba rechazarse. Confuso porque inmediatamente se enfrasca en una artificial línea argumental (puntos 6 y 7 de la Resolución) que pretende separar la «determinación» de la ley aplicable de la «elección» de la ley aplicable, para lo cual trae a colación la posibilidad abierta por el art. 5 del Reglamento Roma III en materia de ley aplicable a la separación y al divorcio. Línea que también se queda en el limbo, sin ser avalada o refutada y, lo que produce más —o la mismaperplejidad, sin saber a dónde conducía. Porque, «no obstante» — dice la DGRN, y esto suponemos que se refiere a los dos amagos de solución- en el caso concurren circunstancias especiales que conducen a la DGRN a considerar «suficientemente acreditada la existencia de la sociedad de gananciales entre los esposos».

3. Las circunstancias especiales a las que se refiere la DGRN no son otras que la creencia de los cónyuges de que su régimen económico era el de gananciales, el de ha- 
berlo manifestado así ante un Notario y el haber inscrito en el Registro civil (en 2014) la escritura de capitulaciones en la que se contenían tales afirmaciones; escritura que da origen a la negativa del registrador. La situación es en cierto modo cómica: la mera existencia de la escritura cuyo contenido el registrador defiende que no se ajusta a la ley, es el elemento fundamental para avalar la legalidad de su contenido (si se me permite el trabalenguas).

No quiere la DGRN entrar en el tema de la ley aplicable. Prefiere quedarse en el de la determinación concreta del régimen económico matrimonial. Pero no puede evitarlo porque antes de las capitulaciones matrimoniales discutidas no había habido ninguna otra. El régimen económico del matrimonio era el (un) régimen legal. Y es en el punto 9 de la Resolución donde encontramos la suculenta respuesta: «nada impide que la laguna legal quede voluntariamente integrada por la decisión de ambos esposos reconociendo, con carácter retroactivo al inicio de su matrimonio, la aplicación de la ley española».

Es una respuesta a la altura de los tiempos: moderna, posible y poco meditada si queremos exportarla con carácter general a los supuestos de matrimonios celebrados entre la Constitución y la referida Ley 21/1990. ¿La ley aplicable será la que elijan los cónyuges y esta elección tendrá carácter retroactivo? ¿Cualquier ley? ¿En las relaciones internas y en las relaciones con terceros? ¿Cuántas veces podrán cambiar la elección según les convenga, también con carácter retroactivo? Esta elección, si nos fijamos en el caso, puede ser tácita y, de cualquier manera, no sabemos cuál es la ley aplicable cuando no haya habido tal «elección».

4. Probablemente la DGRN falló en justicia. Probablemente el mensaje para el registrador era que no había que ser tan tiquismiquis; que no había contienda o problema conocido, salvo el que él mismo planteaba negándose a inscribir el reparto efectuado. Mas, habiendo contienda, entre cónyuges o entre éstos y terceros, con el patrimonio de por medio, discurso y solución habrían de ser más cuidadosos y mejor argumentados. Y esto hace que la solución, que aún se espera para este grupo de casos, no pueda ser generalizada.

\subsection{Responsabilidad del fabricante por los productos defectuosos}

2015-35-Pr

RESPONSABILIDAD DEL FABRICANTE POR LOS PRODUCTOS DEFECTUOSOS.-Ley aplicable._Accidente aéreo.-Convenio sobre Ley Aplicable a la Responsabilidad por Productos, hecho en La Haya el 2 de octubre de 1973.

Preceptos aplicados: Convenio sobre Ley Aplicable a la Responsabilidad por Productos, hecho en La Haya el 2 de octubre de 1973.

Sentencia del Tribunal Supremo (Sala 1. ${ }^{a}$ ) núm. 649/2014, de 13 enero de 2015. Ponente: Rafael Sarazá Jimena.

\section{F.: Aranzadi Westlaw, RJ 2015/612.}


FALLAMOS: 1. Desestimar los recursos extraordinario por infracción procesal y estimar en parte los recursos de casación interpuestos por las entidades "Honeywell Internacional, INC»y "Aviation Communications and Surveillance Systems», contra la Sentencia núm. 230/2012, de 7 de mayo, dictada por la sección decimoséptima de la Audiencia Provincial de Barcelona, en el rollo de apelación núm. 609/2010 .

2. Casamos en parte la expresada sentencia, y acordamos modificarla en los siguientes extremos:

2.1.-Eliminar del fallo la declaración de que hubo defecto de diseño del producto, así como que las demandadas "no hicieron lo necesario para subsanar los problemas".

2.2.-Declarar que los defectos del producto están directamente vinculados y son la causa del accidente aéreo en el que fallecieron los familiares de los ahora demandantes conjuntamente con la actuación del centro de control aéreo de Zúrich.

2.3.- Reducir a la mitad las indemnizaciones a cuyo pago se condena a Aviation Communications and Surveillance Systems.

2.4.-Las indemnizaciones fijadas en la sentencia del Juzgado de Primera Instancia devengarán desde la fecha de esa sentencia el interés legal incrementado en dos puntos. Ese mismo interés, calculado sobre el incremento que suponen las indemnizaciones finalmente fijadas, se devengará desde la fecha en que se dictó la sentencia de la Audiencia Provincial.

3. Se mantiene el resto de pronunciamientos de la sentencia recurrida, a salvo de lo que sigue en materia de costas.

4. Se condena a las recurrentes al pago de las costas de los recursos extraordinarios por infracción procesal. No procede imposición de costas en ninguna de las instancias, ni de las correspondientes a los recursos de casación. Se acuerda la pérdida de los depósitos constituidos para interponer los recursos extraordinarios por infracción procesal y la devolución de los depósitos constituidos para la interposición de los recursos de casación.

Nota. 1. La sentencia del TS que anotamos desarrolla aspectos de Derecho internacional privado (en adelante DIPr) con mucha extensión y detalle. Lo mismo que la Sentencia de la AP de Barcelona (Sección 15. ${ }^{\text {) }}$, de 7 de mayo de 2012, que confirma en lo esencial. El instrumento normativo protagonista es el Convenio de La Haya de 2 de octubre de 1973 sobre ley aplicable a la responsabilidad por productos (en adelante CH73). Se aprecia que partes y tribunales que conocieron del caso estaban ilustrados con informes de especialistas en Dipr y en Derecho comparado. Por tanto, sigue una mera reseña de dicha sentencia de más de 50 páginas (más de 80 la de la AP).

No es extraña la densidad jurídica del caso. Este trae causa del accidente que protagonizaron al chocar en pleno vuelo un Boeing de la DHL y un Tupolev de BAL el 1 de julio de 2002 a la altura de Überlingen (Alemania) a la orilla del lago de Constanza. Familiares de los ocupantes y otras entidades reclamaron en diversas instancias. La que interesa es la reclamación civil de indemnización por productos defectuosos instada por familiares y cónyuges. El producto defectuoso era el sistema anti colisión TCAS II, versión 7.0, que había de prevenir choques en vuelo, contemplando, entre otras cosas, las nuevas instrucciones a dar si, por alguna razón, alguno de los aviones en peligro no atendían las primeras instrucciones para evitar la colisión. Dicho aparato había sido fabricado por las demandadas Honeywell (Nueva Jersey) y ACCS (Arizona) y estaba instalado en ambas naves. Además de este procedimiento, las autoridades suizas habían declarado la responsabilidad de los servicios de control aéreo del aeropuerto de Zúrich (los hechos al respecto se relatan en el FD 1.2 de la STS; 
véase también HERNÁNDEZ RodRíGUEZ, A., «Accidentes aéreos y forum non conveniens. Algunas cuestiones en torno al asunto Honeywell en España», Cuadernos de Derecho transnacional, 2012, octubre, pp. 308 y ss.).

La acción en primera instancia fue entablada en un Juzgado de PI de Barcelona en abril de 2007. El caso llegó a los tribunales españoles porque las demandadas se sometieron a los mismos (HERNÁNDEZ RodRíguez, A., op. cit., p. 313) tras la declaración de forum non conveniens efectuada por un tribunal de distrito federal de Nueva Jersey en 2005. Este tribunal consideró que estaban en mejor situación para conocer del asunto los tribunales de Barcelona, lugar de destino del vuelo de BAL (véase HERRANZ BALLESTEROS, M., «Conflicto de jurisdicciones y declinatoria de la competencia: los asuntos Honeywell y Spanair», Cuadernos de Derecho transnacional, 2013, octubre, pp. 592-609).

2. Son frecuentes los reproches que el TS hace a las recurrentes acerca de su planteamiento de las cuestiones y de las afirmaciones que hacen respecto de la sentencia de la AP (DF 4, último párrafo; FD 6.3; FD 8.7). Si bien la competencia judicial internacional de los tribunales españoles no es objeto de debate, la resolución de los recursos extraordinarios por infracción procesal interpuestos por las sociedades americanas demandadas contiene aspectos de gran interés, en la frontera de lo substantivo. El más destacable es el relativo a la «carga de la prueba» de la defectuosidad del producto. Aquí el TS, ante el reproche de la vulneración de las reglas de la carga de la prueba, establece que, a diferencia de otros ordenamientos, la regla del art. 217 de la LEC se encuentra entre las normas relativas a la sentencia (FD 14.2), y entiende que reglas sobre la "preponderance of the evidence» no son de carga de la prueba, sino de nivel exigible de prueba, a valorar según la ley aplicable al fondo de conformidad con el art. 8.8 del $\mathrm{CH} 73$. Es de destacar asimismo que dicho examen, que se remite a la resolución de los recursos de casación, se efectúa respecto de las acciones por «wrongful death» y ya no para apreciar las acciones por daños punitivos, que habían quedado definitivamente desestimadas en instancia (FD 14. 3, 4 y 5).

3. Las cuestiones substantivas resueltas en el recurso extraordinario de casación son las que siguen:

a) Calificación de la pretensión y ley aplicable: responsabilidad por productos (FD 16). Las acciones ejercidas son las relativas al defecto del producto anti colisión, no a su inutilidad por quien lo adquirió por título contractual (también FD 24). Por tanto, se trata de una acción de responsabilidad por productos cuya ley aplicable queda determinada por el CH73. Dicha ley aplicable es la que señala el art. 6 del CH73, dado que la agrupación de contactos con que se construyen los arts. 4 y 5 no se cumple. En particular, la adquisición de los títulos de transporte de las víctimas no se puede reducir a "adquisición del producto» defectuoso (art. 5 del $\mathrm{CH} 73$ : «No obstante lo dispuesto en el artículo 4, la legislación aplicable será el Derecho interno del Estado de residencia habitual de la persona directamente perjudicada en el caso de que dicho Estado sea también: ... b) el Estado en cuyo territorio hubiese sido adquirido el producto por la persona directamente perjudicada»). Por tanto, en aplicación del art. 6 del $\mathrm{CH} 73$ y dado que no se ha optado por solicitar la aplicación de la ley interna alemana correspondiente al lugar del daño, se aplican para cada uno de los demandados la correspondiente al «Derecho interno del Estado en que se halle el establecimiento principal de la persona a quien se le imputa la responsabilidad»; es decir, con la concreción del art. 12 del CH73, la ley de Nueva Jersey respecto de la reclamación contra Honeywell y la de Arizona respecto de la efectuada contra ACCS. Indica correctamente el TS «que los defectos imputados al producto sean o no ciertos, 
o que efectivamente constituyan defectos que conforme a la ley aplicable den lugar a a responsabilidad del fabricante, es la cuestión de fondo a discutir en el litigio, que no afecta a la determinación de la ley aplicable sino a la prosperabilidad de la acción».

b) Legitimación activa: calificación no sucesoria (FD 18). Habiéndose ejercido acciones por personas a las que la ley aplicable reconoce un derecho originario y también acciones de supervivencia que son un derecho originario de las víctimas eventualmente transmisible por herencia, ha de aclararse que estas últimas acciones quedaron definitivamente desestimadas en instancia. No se plantea por tanto la ley aplicable a la sucesión en dichas acciones (art. 8.5 del CH73); las que subsisten («wrongful death»), atribuidas directamente a los familiares según la ley aplicable al fondo de la responsabilidad por productos se rigen (art. 8.6 del CH73) por el Derecho interno de los estados de Arizona (ACCS) y de Nueva Jersey (Honeywell) (véase REESE, W. L. M., «Explanatory Report del Convenio de la Haya de 2 octubre 1973 sobre ley aplicable a a responsabilidad por productos», Actes et documents de la Douzième session de la Conférence de la Haye de droit international privé, 1972, 1974, p. 266).

c) El producto defectuoso y la relación de causalidad. El indicado sistema TCAS II versión 7.0 se analiza en su triple vertiente de defecto de diseño, de fabricación y de información sobre el producto, distinguiendo en cada caso según el Derecho de uno y otro Estado de los Estados Unidos (FD 24). Se analiza asimismo y se niega (FD 22, 27) que haya conflicto entre la legislación estatal y la federal estadounidense administrativa relativa a la seguridad aérea y autorizaciones de productos de seguridad. En cuanto a la relación de causalidad entre producto defectuoso y daño (FD 25) se encuentra en el defecto de información en el manual del piloto elaborado por los fabricantes, por insuficiente advertencia sobre riesgos, lo que influyó en el manual de vuelo de la aerolínea. No existe en cambio defecto de diseño, al estar éste estrictamente condicionado por la normativa federal, que no se había adaptado todavía a las soluciones ensayadas para solventar el defecto del producto (FD 27). El TS confirma que este defecto de información y la relación de causalidad con el accidente existe de conformidad con las leyes de Arizona y de Nueva Jersey, con cita además del Restatement of the Law, Third, Torts [art. 2.c) Capítulo I]. (Véase una reciente contextualización de estas nociones en RajNERI KaRAgEORGEVITCH, E., «La notion de défectuosité du produit dans les jurisprudences des pays européens», Revue internationale de droit comparé, 20015-1, pp. 185-205).

d) Concurrencia de causas. Se confirma la irrelevancia a estos efectos de la conducta de la tripulación del vuelo de BAL, siguiendo las apreciaciones efectuadas en instancia a raíz de lo resuelto por la vía penal en Suiza y sin que tenga incidencia la existencia de una sentencia firme que condena a indemnizar a una de las compañías aéreas (STS de 18 de julio de 2011, AEDIPr 2011/78; véase HERnáNDEZ RodRíguEZ, A., op. cit., p. 314), ya que esto sucede bajo un régimen de responsabilidad objetiva (FD 29.1 y 2). Distinto es el caso del control aéreo suizo, cuyas graves deficiencias se tienen por ciertas (FD 29.4). Ahora bien, en el caso de Honeywell, la disminución de la condena atendida la concurrencia de causas prevista bajo ciertas condiciones en el Derecho de Nueva Jersey no es aplicable si el causante concurrente no es parte en el procedimiento (FD 30). Respecto de ACSS, la falta de acreditación suficiente de las reglas especiales del Derecho de Arizona alegadas por los demandantes determina la aplicación de las reglas generales de ese Estado, conforme a las cuales la responsabilidad es mancomunada entre los codemandados (DF 31.2 y 3); además, el TS, dado el contexto internacional del proceso, da por cumplida la condición de llamada al proceso del tercero por parte del demandado con las propias alegaciones hechas en la contesta- 
ción a la demanda por ACSSS relativas a la corresponsabilidad de la tripulación del Tupolev y del control aéreo suizo, al que se atribuye un 50 por cien; en consecuencia, estimando aquí en parte el recurso de casación de ACCS, la responsabilidad de ACCS se reduce al 50 por cien por concurrir con la de Honeywell y dicho 50 por cien se divide en dos partes atendiendo la corresponsabilidad del control aéreo suizo (FD 31. 4, 5 y 6), sin que procedan otras reducciones por apreciaciones de equidad (FD 33).

e) Actos propios y buena fe: Por último, el TS declara obitem dictum que las exigencias de buena fe, no abuso de derecho o fraude procesal ex arts. $7.1 \mathrm{del} \mathrm{Cc}, 11.3$ de la LOPJ y 247.2 de la LEC son de orden público en cualquier proceso seguido en España. No reputa contrario a estas normas el que los demandantes hayan seguido procesos en Estados Unidos (interrumpido, supra 1), en Suiza (penales no iniciados por los demandantes) y en España (civiles contra una de las compañías, supra d), sin haberse reducido o limitado la responsabilidad reclamada en España en atención a las responsabilidades ventiladas en dichos procesos (FD 20).

\author{
Joaquim J. Forner I DelayguA* \\ Universitat de Barcelona \\ http://dx.doi.org/10.17103/redi.67.2.2015.3b.16
}

\title{
3.5. Sucesiones internacionales
}

2015-36-Pr

LEY APLICABLE A LA SUCESIÓN MORTIS CAUSA.-Reenvío de retorno.-Condiciones y límites.-Armonía internacional de soluciones.-Solución del Reglamento 650/2012.

Preceptos aplicados: arts. 9.8 y 12.2 del CC.

Sentencia TS (Sala de lo Civil, Sección 1. a) de 12 de enero de 2015. Magistrado Ponente: Francisco Javier Orduña Moreno.

\section{F.: Aranzadi Westlaw, JUR 2015/59527; RJ 2015/263.}

2. Con relación al contexto argumentativo de la parte recurrente debe señalarse, en primer término, que no puede desconocerse que la reciente doctrina jurisprudencial de esta Sala, si por tal entendemos la desarrollada a partir de a Sentencia de 15 de noviembre de 1996, ha flexibilizado la aplicación meramente literal del reenvio, tal y como se contempla en el artículo 12.2 (donde el reenvío de retorno sólo se acepta en favor del ordenamiento jurídico español), afirmando la necesidad ab initio (desde el inicio) de ponderar su efectiva aplicación a la concurrencia de otros criterios. Entre estos, se ha señalado la conveniencia de que el reenvio lleve a un resultado acorde con los principios generales del Derecho español de forma que, en su caso, entrañe una mayor justicia en relación a los intereses en juego (STS de 21 de mayo de 1999). Pero sobre todo, caso que nos ocupa, se ha destacado el valor referencial que desarrolla la figura del reenvío como instrumento al servicio de la armonización de sistemas jurídicos de los Estados (la ya citada STS de 15 de noviembre de 1996).

* Esta colaboración se enmarca en el Proyecto titulado «La aplicación de los instrumentos comunitarios en materia de Derecho internacional privado por los tribunales españoles: balance y perspectivas», financiado por el Ministerio de Economía y competitividad, Dirección General de Investigación Científica y Técnica, y con referencia DER2012-36920. 
No obstante, y pese a este avance doctrinal, debe puntualizarse, en segundo término, que este valor referencial de armonización tampoco puede ser interpretado, a su vez, de un modo absoluto o excluyente, sino que viene también modulado por el propio alcance normativo de la figura, esto es, por el ámbito de aplicación que se le reconoce al reenvío (sólo se admite el reenvio de retorno), y por su sujeción a los objetivos del Derecho internacional privado que presente el Derecho interno español en la materia objeto de análisis.

Esto lleva a que en determinadas ocasiones, y en relación con el ámbito sucesorio, como ha señalado la doctrina jurisprudencial de esta Sala con relación al artículo 9.8 del Código Civil, que el reenvío de retorno no deba ser admitido cuando su aplicación comporte, bien un fraccionamiento de la unidad legal de la sucesión, o bien, un fraccionamiento del carácter universal que debe acompañar a la misma, de forma que resulte aplicable la ley nacional del causante en el momento de su fallecimiento.

En este contexto, debe señalarse que el principio de armonía no constituye, en rigor, un criterio interpretativo en la aplicación del expediente del reenvío.

En el presente caso, esto es lo que ocurre, pues la remisión realizada a la legislación inglesa comporta el reenvío de retorno al ordenamiento jurídico español sin que se produzca, al ser el único bien hereditario y además tener el domicilio en España, el fraccionamiento del fenómeno sucesorio señalado respecto de la sucesión del causante.

Todo ello, sin perjuicio de las modificaciones sobre la materia que se deriven de la plena aplicación del Reglamento 650/2012 del Parlamento Europeo y del Consejo, de 4 de julio de 2012.

Nota. 1. Cuando esta nota vea la luz, el art. 12.2 del CC habrá comenzado a difuminarse en lo que atañe a las sucesiones internacionales, prácticamente el único ámbito en el que ha podido desarrollarse nítidamente en los términos jurisprudenciales por todos conocidos. El Reglamento 650/2012 ya se estará aplicando a las sucesiones abiertas a partir del día 17 de agosto de 2015, y el régimen del CC quedará relegado a las de causantes fallecidos con anterioridad a esa fecha. Cumple recordar que aún seguirán funcionando las normas de nuestro DIPr interno (art. 9.8 y 12 del CC por lo que atañe al tema que ahora nos ocupa) durante el tiempo en que las sucesiones abiertas antes de la referida fecha requieran del concurso del DIPr. Pero tales normas irán progresivamente dejando su puesto a las del Reglamento. El art. 9.8 del CC seguirá, eso sí, reglamentando los problemas de Derecho interregional.

La STS que anotamos tiene la importancia de volver sobre las condiciones para la admisión del reenvío de retorno a la ley española que habían fijado sus precedesoras y, especialmente, de rectificar una que llamaba la atención por extraña y, sobre todo, por hacer una lectura errónea de uno de los tópicos en los que siempre se ha basado el expediente del reenvío: la armonía internacional de soluciones. En esta breve nota, veremos cómo se produce esta rectificación (3) y aprovecharemos la ocasión para adelantar cuál sería la respuesta al caso de ser de aplicación el Reglamento de sucesiones, recogiendo la invitación del estrambote con que el TS cierra su Fundamento de Derecho segundo (4); antes pondré de manifiesto alguna peculiaridad del contenido del testamento (2).

2. El supuesto de hecho no puede ser más típico: sucesión de nacional del Reino Unido (inglés) con último domicilio en España y con testamento instituyendo a su esposa como única heredera de todos los bienes, derechos y acciones localizados en España; la hija del causante solicita que se la declare como legitimaria de un tercio del haber hereditario y del tercio de mejora, sin perjuicio del usufructo que sobre este 
tercio corresponda a la viuda. En definitiva, pide que se declaren sus derechos sucesorios conforme a lo establecido en el CC español. La primera instancia desestima la demanda; la apelación la estima y el TS ratifica la solución de la segunda instancia declarando no haber lugar al recurso de casación, por considerar de aplicación el CC.

Antes de entrar en el razonamiento concreto de nuestro Alto Tribunal quisiera llamar la atención sobre la peculiaridad de las cláusulas testamentarias que se reproducen en la Sentencia. En efecto, llama la atención por una parte que el testamento verse exclusivamente sobre los bienes sitos en España, sin perjuicio de la validez de otros testamentos que el causante hubiere otorgado o llegase a otorgar en su país y que fuesen compatibles con el discutido. Nada que objetar a esta limitación y a esta posible compatibilidad. Se trata, parece ser, de una práctica en absoluto inhabitual; mas en el párrafo final, deja a salvo las legítimas teniendo en cuenta el valor de todos sus bienes, cualquiera que fuese su lugar de situación. Probablemente se trate de una mera cláusula de estilo introducida por el notario con el objetivo de evitar la preterición y, todo ello, bajo la eventual aplicación de una ley que —contrariamente a la nacional del testador- contemplase tales realidades jurídicas (la legítima y la preterición). En definitiva, se trata de un testamento que podría pasar fácilmente por un testamento de Derecho común.

En cualquier caso, los datos del supuestos identifican toda la herencia con único bien inmueble localizado en España.

3. Por lo que atañe al reenvío, la sentencia merece dos comentarios. El primero, que hace total abstracción del hecho de encontrarnos ante una sucesión testamentaria. Algunas voces se habían alzado entre nuestra doctrina para eliminar el reenvío en tales casos [Virgós SoRIANo, M., "Derecho sucesorio y reenvío: la respuesta del sistema español», Anales de la Academia Matritense del Notariado, T. XLII, Madrid, 2004, pp. 181-210, p. 185 y 204-208; FonTANELLAS Morell, J., en su nota a la Sentencia de la Audiencia Provincial de Madrid (sección 25. ${ }^{\text {) }}$ núm. 391/2013, de 27 de septiembre, REDI, 2014-30-Pr]. Esta posibilidad, basada en el respeto de la voluntad del causante ajustada a su ley nacional, quizá sea menos defendible en función de cómo interpretemos las cláusulas testamentarias tal cual vimos en el punto anterior. En efecto, como he señalado, el contenido del testamento salvando las legítimas no parece indicar una clara y contundente afirmación de la libertad de testar que el causante ostentaría conforme a su ley nacional. Obviamente, el TS no ha sido consciente de este hecho, dado que esta autonomía de la voluntad material no está presente en el argumentario de su jurisprudencia sobre el reenvío.

Sin embargo, lo más destacable es la aseveración de que «debe señalarse que el principio de armonía no constituye, en rigor, un criterio interpretativo en la aplicación del expediente del reenvío». En efecto, ya denuncié en su momento que la exigencia de la jurisprudencia del TS en esta materia era una mala comprensión de la idea de armonía internacional de soluciones que rodea a la técnica del reenvío ( $D o s$ cuestiones de actualidad en el reciente Derecho internacional privado de sucesiones: los derechos del cónyuge supérstite y el reenvío», Estudios de Derecho civil. Homenaje al Profesor Francisco Javier Serrano García, Valladolid, Universidad de Valladolid, 2004, pp. 131-157, pp. 152-153). Bienvenida sea la rectificación porque la interpreto como abandono de su errónea visión anterior, no porque pueda sostenerse sin ambages que el principio de armonía internacional de soluciones — correctamente entendido- no sea un elemento consustancial al reenvío.

4. Para concluir, veamos cómo se resolvería el tema a la luz del Reglamento, significando, simplemente, que la salvedad que hace el TS a «las modificaciones sobre 
la materia que se deriven de la plena aplicación del Reglamento 650/2012...», en nada afecta al caso controvertido.

Pues bien, la aplicación del Reglamento en este caso conduciría a la misma solución que proporciona el magro arsenal normativo del CC. De los datos que el texto de la sentencia nos ofrece podemos derivar que el causante tuvo su última residencia habitual en Jávea ( «no resultando discutida su residencia habitual en esa localidad» señala la sentencia) por lo que en virtud del art. 21.1 del Reglamento la ley de su última residencia habitual regiría su sucesión. No parece existir ninguna ley más estrechamente vinculada (art. 21.2 del Reglamento), ni ha mediado professio iuris a favor de la ley nacional del causante (art. 22 del Reglamento). Aunque tal elección de ley puede ser tanto expresa como tácita («La elección deberá hacerse expresamente en forma de disposición mortis causa, o habrá de resultar de los términos de una disposición de ese tipo»), ya señalé (supra núm. 2) que el contenido del testamento se corresponde con un testamento sometido a una sistema como el del CC. La alusión a la salvaguarda de las legítimas imposibilita concluir que hay elección tácita de la ley inglesa. El art. 21.1 más el art. 36 del Reglamento (remisión a sistema plurilegislativo) nos conduciría a la aplicación del CC.

Si alteramos las circunstancias del caso y situamos la última residencia habitual del causante en el Reino Unido - supuesto que no habrá de ser infrecuente en la práctica española - también se llegaría a la misma solución aunque por otra vía. Los tribunales españoles podrían ser competentes en virtud del art. 10.1.b o 10.2 del Reglamento (según se diesen o no las condiciones que en el primero ser expresan). Descartada la professio iuris como una de las situaciones en las que no se admite el reenvío, nos encontraríamos ante un reenvío de retorno de la ley de un tercer Estado (porque el Reino Unido es un Estado tercero a los efectos del Reglamento de sucesiones) a la ley española (art. 34.1.a del Reglamento), en virtud de la remisión que la ley de la última residencia habitual haría a la lex rei sitae para la sucesión inmobiliaria —única que en este caso se ventilaba.

5. La STS se encarga de corregir una errónea visión de la armonía internacional de soluciones en materia del reenvío previsto por el art. 12.2 del CC que, como he señalado, irá teniendo cada vez menos recorrido. La regulación del Reglamento en materia de reenvío parece fundamentarse en esa idea de armonía internacional de soluciones («coherencia internacional» dice el Cdo. 57), bien entendida, eso sí. En todo caso, no deja de resultar curioso que la revolución que supone el Reglamento no habría afectado al supuesto que resolvió el TS.

Santiago Álvarez GonZÁLEZ*

Universidad de Santiago de Compostela http://dx.doi.org/10.17103/redi.67.2.2015.3b.17

\footnotetext{
* La presente colaboración se realizó en el marco del Proyecto de Investigación del Plan Nacional de I+D+i, «Sucesiones internacionales. El Reglamento 650/2012 y su interacción con el Derecho civil nacional» [Ref. DER2013-43391-R], subvencionado por el Ministerio Ciencia e Innovación y el FEDER, y dentro del Programa de consolidación y estructuración de unidades de investigación competitivas del Sistema universitario de Galicia [exp. GPC2014/024].
} 